Leaf area index for biomes of the Eastern Arc Mountains : Landsat and SPOT observations along precipitation and altitude gradients

\author{
Pfeifer, Marion
}

2012

Pfeifer , M , Gonsamo , A , Disney , M , Pellikka , P \& Marchant , R 2012 , ' Leaf area index for biomes of the Eastern Arc Mountains : Landsat and SPOT observations along precipitation and altitude gradients ' , Remote Sensing of Environment, vol. 118 , pp. 103-115 . https://doi.org/10.1016/j.rse.2011.11.009

http://hdl.handle.net/10138/44814

https://doi.org/10.1016/j.rse.2011.11.009

publishedVersion

Downloaded from Helda, University of Helsinki institutional repository.

This is an electronic reprint of the original article.

This reprint may differ from the original in pagination and typographic detail.

Please cite the original version. 


\title{
Leaf area index for biomes of the Eastern Arc Mountains: Landsat and SPOT observations along precipitation and altitude gradients
}

\author{
Marion Pfeifer ${ }^{\mathrm{a}, *}$, Alemu Gonsamo ${ }^{\mathrm{b}}$, Mathias Disney ${ }^{\mathrm{c}, \mathrm{d}}$, Petri Pellikka ${ }^{\mathrm{e}}$, Rob Marchant ${ }^{\mathrm{a}}$ \\ a York Institute of Tropical Ecosystem Dynamics, Environment Department, University of York, Heslington, York, YO10 5DD, UK \\ b Department of Geography and Program in Planning, University of Toronto, 100 St. George Street, Toronto, Canada M5S 3G3 \\ c Department of Geography, University College London, WC1E 6BT London, UK \\ d NERC National Centre for Earth Observation (NCEO), UK \\ e Department of Geosciences and Geography, University of Helsinki, P.O. Box 64, Gustaf Hällströmin katu 2, Helsinki 00014, Finland
}

\section{A R T I C L E I N F O}

\section{Article history:}

Received 24 May 2011

Received in revised form 15 November 2011

Accepted 18 November 2011

Available online 17 December 2011

\section{Keywords:}

Leaf area index

Carbon flux

East Africa

Hemispherical photography

SunScan instrument

Vegetation index

Precipitation

SPOT HRVIR

Landsat ETM +

\begin{abstract}
A B S T R A C T
Understanding of mechanisms underlying carbon flux dynamics in the Eastern Arc Mountains and their catchment areas is lacking, due to data shortage (e.g. biome specific canopy structure) and spatial heterogeneity of tropical ecosystems. This study focuses on documenting leaf area index (LAI) for the main biomes in the Eastern Arc Mountains and their surroundings. In situ optical instruments, i.e. hemispherical photography and a SunScan device, were used to acquire ground LAI measurements. Spectral vegetation indices (VIs) extracted from Landsat Enhanced Thematic Mapper (ETM +) and Système Probatoire d'Observation de la Terre (SPOT) reflectance data were used, along with mean annual precipitation (MAP), as explanatory variables of LAI variation. The results indicate that LAI significantly increases with increasing MAP for woody biomes. Implementing long-term MAP as a second predictor variable into the VI-LAI models significantly improved LAI predictions by up to $10 \%$ using the normalised difference vegetation index (NDVI), modified soil adjusted vegetation index (MSAVI 2) and 2-band enhanced vegetation index (EVI 2). Varying forest disturbances and agricultural management practises may have contributed to observed discrepancies of LAI with MAP across biomes. The importance of altitudinal gradients is yet to be explained fully with more study required. However, LAI appears to be higher in low-altitude forests compared to forests at higher altitudes. Our results indicate that SPOT and Landsat-derived VIs, in combination with long-term MAP, may be a suitable tool to develop landscape maps of LAI in Eastern Africa. This study also presents the in situ LAI measurements for further validation of global products for areas that are currently under-represented in Earth Observation (EO) global validation networks.
\end{abstract}

(c) 2011 Elsevier Inc. All rights reserved.

\section{Introduction}

The Eastern Arc Mountains, a chain of mountain blocks stretching across Tanzania to South Kenya, are a major refugium for diverse tropical forests (Mittermeier et al., 2004; Myers et al., 2000). Rapid deforestation trends (Hall et al., 2009) are fuelled by recent intense economic development and population growth, especially in lowland and coastal areas (Ahrends et al., 2010; Lovett et al., 2000). Forests in southern Kenya (Taita Hills and Kasigau) are particularly affected by human activities and only a few disturbed fragments remain (Aerts et al., 2011; Pellikka et al., 2009).

Recently, these tropical forests have received considerable attention because of their high biodiversity and level of species endemism (Burgess et al., 2007; Lovett \& Wasser, 1993), their status as provider of essential ecosystem services to local communities (Bjørndalen,

\footnotetext{
* Corresponding author. Tel.: + 441904 434780; fax: + 441904432998. E-mail address: marion.pfeifer@googlemail.com (M. Pfeifer).
}

1992; Swetnam et al., 2011) and more importantly their role as global carbon sink (Burgess et al., 2010; Lewis et al., 2009).

At lower altitudes, the landscape is dominated by dry woody biomes including deciduous woodlands and savannah systems. Such biomes are highly dynamic, varying across space and time (Bucini \& Hanan, 2007; Furley, 2010; Marchant, 2010). Their extents and structures reflect complex interactions between local fire regimes (Bond et al., 2003, 2005; Govender et al., 2006), substrate and topography (Kambatuku et al., 2011; Schleicher et al., 2011), inter-tree competition (Wiegand et al., 2006), human activities and herbivore pressure (Holdo et al., 2009; Ribeiro, Saatchi, et al., 2008). Maximum tree cover is expected to increase linearly with mean annual precipitation (MAP) up to about $650 \mathrm{~mm} /$ year (Sankaran et al., 2005). While precipitation seasonality drives intra-annual vegetation structure changes. Despite their importance for village communities (Chidumayo \& Kwibisa, 2003), dry woody biomes are understudied (Williams et al., 2008) and their contribution to regional gas fluxes is uncertain due to lack of data on vegetation structure and its interannual changes (Williams et al., 2007), although studies suggest that they are a carbon sink (Taylor \& Lloyd, 1992). 
Vegetation is a key player in ecosystem processes controlling primary productivity and transpiration as well as water and gas exchanges between atmosphere and terrestrial ecosystem (Monteith \& Unsworth, 1990; Running et al., 1999). Linking vegetation structure to vegetation function in ecosystem processes such as carbon flux dynamics and surface water flows (Hill et al., 2006) requires baseline vegetation structure data over large landscape scales (Stoy et al., 2009). However, spatial estimates of biomass and vegetation canopy traits are rare, especially for tropical dry forests and ecosystems in tropical Africa (Kalácska et al., 2005; Schimel et al., 2001).

High spatial heterogeneity in vegetation structure is not accounted for in current dynamic vegetation models (e.g. Doherty et al., 2010) but could potentially alter model predictions for East African vegetation under climate change, which currently produce contradictory reconstructions. Vegetation structure can be assessed on the landscape scale by measuring vegetation canopy traits including leaf area index (LAI) and canopy gap fraction under different precipitation and disturbance regimes. LAI is defined as one half the total leaf surface area per unit ground surface area projected on the local horizontal datum (Chen \& Black, 1992; Gonsamo, 2009). It features as a critical state variable in many ecosystem process models characterising, among others, crop growth, hydrology, numerical weather prediction and carbon cycling (e.g. Anselmi et al., 2004; Borchers et al., 1995; Doraiswamy et al., 2004; Sabater et al., 2008).

As a result of its ubiquity in biogeochemical models, LAI is sometimes prescribed as literature-based estimate for specific plant functional types (Asner et al., 2003; Scurlock et al., 2001). However, global spatial coverage of in situ LAI estimates is inconsistent and there is a significant lack of data for biomes on the African continent. Of the few LAI studies in Africa, most were carried out for crop growth assessment (e.g. Amer, 2010; Chiezey et al., 2004; Oguntunde \& van de Giesen, 2004), and only a few estimated LAI in forest plantations (Dovey \& du Toit, 2006; du Toit \& Dovey, 2005) or natural biomes (Privette et al., 2002; Wasseige et al., 2003; Ribeiro, Shugart, et al., 2008; Mougin et al., 2009; Kraus et al., 2009; Kovacs et al., 2010). Because LAI can vary strongly between regions and within biomes (Asner et al., 2003; Ribeiro, Shugart, et al., 2008), and temporarily with seasons, weather and disturbances (Wasseige et al., 2003; Mougin et al., 2009), such data gaps can introduce substantial errors into global ecosystem models (Launay \& Guerif, 2005; Sabater et al., 2008).

Estimating plot-level LAI can be labour intensive and time consuming (Jonckheere et al., 2004), although indirect approaches (e.g. hemispherical photography, Sunscan-Delta-T, LAI-2000) now enable more timeefficient LAI estimates for rapid canopy structure assessments over larger areas. Remote sensing has extended the capability of observing foliage changes from the ground (Garrigues et al., 2008; Wasseige et al., 2003). LAI estimation at landscape, regional or global scales relies on remotely sensed optical measurements using either physically based or empirical models (Stoy et al., 2009; De Kauwe et al., 2011).

Empirical models for estimating LAI from remotely sensed data typically rely on spectral vegetation indices (VIs), formed by arithmetic combinations of two or more spectral bands of optical sensor data. VIs exploit the spectral contrast between various spectral bands, typically visible red and near-infrared, to relate canopy physical traits to reflectance. VIs correlate with LAI and productivity (e.g. Jiang et al., 2008; Pettorelli et al., 2011; Sims et al., 2006; Sjöström et al., 2011). However, their links to ecological traits are region-specific which can introduce aggregation errors during upscaling from plot-level to moderate or coarse resolution of satellite data (Pfeifer et al., in press).

In this study, we focus on major biomes of the Eastern Arc Mountains and their catchment areas in South-west Kenya and Tanzania aiming to document and estimate biome-specific LAI and its spatial variation at landscape scales. We set out to address the following questions: (i) can typical East African woody biomes be distinguished according to their LAI? (ii) Does precipitation affect LAI measured for biomes? And (iii) if so, can precipitation be included as additional explanatory model variable in VIs-LAI models in order to improve large scale estimation of
LAI? We document ground measurements of LAI in tropical monsoon biomes of Kenya and Tanzania. We develop LAI-VI models using three VIs that could subsequently be used to upscale LAI from plot to landscape scale using satellite imagery, and we test the significance of MAP as an additional explanatory variable for changing LAI.

\section{Material and methods}

\subsection{Study site}

The study was carried out in the Eastern Arc Mountains and their catchment areas (Fig. 1). Main biomes include tropical montane and lowland forests, deciduous woodlands (sensu Miombo; dominated primarily by genera Brachystegia, Julbernadia and Isoberlinia), bushlands sensu savannah, croplands and forest plantations (Table 1). Forests are mainly found in the mountains, although a few coastal and lowland forests can still be found. Fire-prone woodlands and bushlands (Fig. 2) dominate in lower altitudes. They are characterised by lower tree canopy height and density and thus lower above-ground biomass (Williams et al., 2008). Structure and productivity of woody biomes in Eastern Africa is assumed to vary primarily with precipitation (Hely et al., 2006). Precipitation in the study area is spatially variable and strictly seasonal (Marchant et al., 2006; Nicholson, 2000; Schreck \& Semazzi, 2004). Woodlands and forests are either used for timber, charcoal production and food, or are converted to cultivated land including forest plantations and agricultural crops (Chidumayo \& Kwibisa, 2003). A range of land management schemes exist aimed at conservation of forests and woodlands or at their management for resource use (IUCN and UNEP-WCMC 2010; http://www.unep-wcmc.org/protected_areas/protected_areas).

\subsection{Ground measurement sampling periods}

Four fieldwork campaigns were carried out to acquire biomespecific estimates of LAI. In January 2007, hemispherical images were collected in forest fragments located in the Taita Hills (Kenya), which represent the northern border of the Eastern Arc Mountains (Table 2). In January 2010, hemispherical images were collected in fragments of montane forests and one pine plantation in Kasigau (Kenya). Independently, Sunscan-Delta-T measurements and further sets of hemispherical images were obtained in January and July 2010 in tropical montane forests, lowland and coastal forests, woodlands, bushland, and a range of crop types and forest plantations in Tanzania's Eastern Arc Mountain blocks and their catchment areas (Table 1).

\subsection{Ground measurements of LAI}

We used two indirect methods to estimate in situ LAI that are based on non-contact gap fraction inversion measuring radiation transmission through the canopy. The SunScan (Delta-T Devices Ltd., Cambridge) instrument was used in selected biomes (Table 1). The SunScan instrument measures photosynthetically active radiation (PAR) below the canopy via 64 sensors and LAI is derived using a simplified radiative transfer approximation for direct and diffuse attenuation through the canopy (Webb et al., 2008). The SunScan instrument is optimised for low regular canopies and has been shown to capture the high LAI gradient in agricultural crops (Wilhelm, 2000) and to correlate significantly with LAI estimates derived from destructive sampling for rice fields (Sone et al., 2009).

High-resolution RGB images were taken in most biomes through a hemispherical (fish-eye) lens looking vertically upward beneath a vegetation canopy (Jonckheere et al., 2005b). The 'levelled' hemispherical photographs were acquired normal to a local horizontal datum by orienting the optical axis of the lens to local zenith (Gonsamo \& Pellikka, 2008). Measurements were performed under overcast conditions to minimise anisotropy of the sky radiance (Jonckheere et al., 2004). Images were acquired using a tripod with the camera levelled 


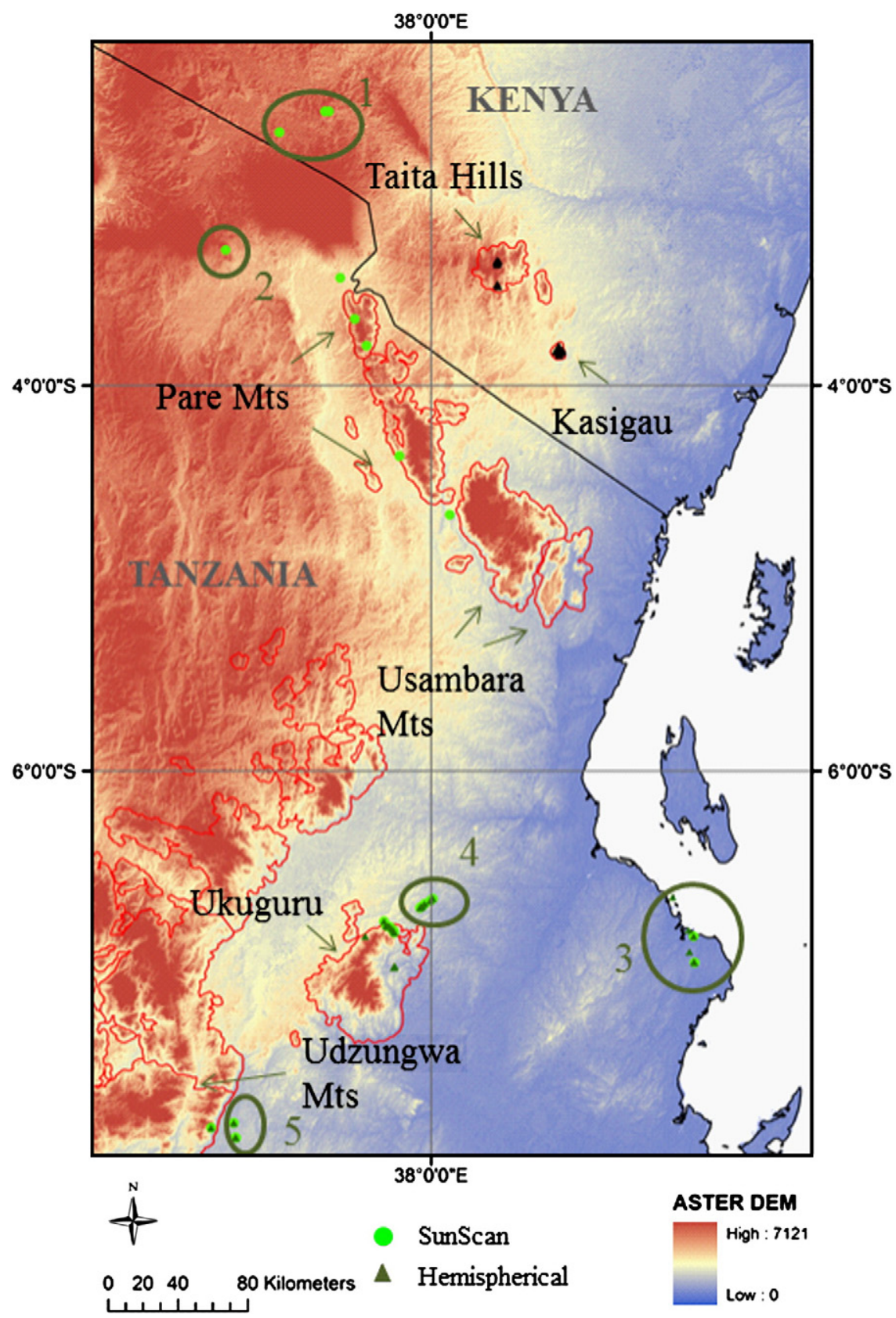

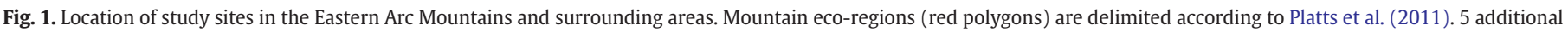

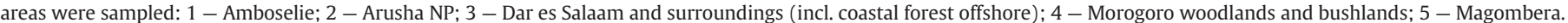
Green dots - SunScan measurements. Green (camera system 3) and black triangles (camera systems 1 and 2) - Collection of hemispherical images.

about $1 \mathrm{~m}$ above ground. A compass was used to ensure the upper picture margin was always facing northward

Three different camera systems were used (Table 2). Images in Taita Hills were taken with an 8 mega pixel Nikon Coolpix 8800 VR digital camera equipped with a fish-eye Nikon FC-E9 lens adapter (System 1). Pictures in Kasigau were taken with a 12.3 megapixel Nikon D5000 SLR digital camera equipped with a Sigma $4.5 \mathrm{~mm}$ F2.8 fish-eye lens adapter (System 2). Pictures in southern and coastal areas of Tanzania were taken with a 12.2 megapixel Canon EOS 450D equipped with a Sigma 4.5 mm F2.8 fish-eye lens adapter (System 3). The cameras were calibrated to define optical centre and projection function. To correct for possible lens distortions, System 3 was calibrated following the CAN-EYE V6 manual (Weiss \& Baret, 2010).

Manual exposure settings are usually recommended when acquiring hemispherical photographs, based on reference measurements made either using a spot light meter or the same fish-eye lens, the latter being the ideal approach (Zhang et al., 2005). Here, we have used the same fish-eye lens to determine the standard exposure. As large gaps were not often possible to find and the sky brightness from the surrounding sloping ground has a large contribution in the measured reference exposure, we have primarily relied on overcast sky condition and exposure adjustment in reference to the measured in-stand automatic exposure as recommended by Zhang et al. (2005). As such, we have acquired a series of photographs using automatic exposure, and 1 and 2 stops underexposure relative to the in-canopy automatic measures. Among these photographs, we have selected visually those which gave the best contrast between foliage and sky.

The VAlidation of Land European Remote Sensing Instruments (VALERI: http://w3.avignon.inra.fr/valeri/) project recommends specific ground measurement sampling schemes to characterise biophysical 
Table 1

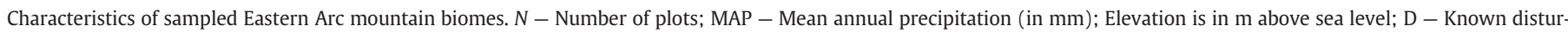

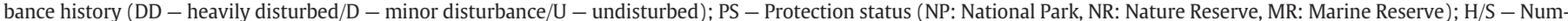
ber of plots with hemispherical images/SunScan data.

\begin{tabular}{|c|c|c|c|c|c|c|c|c|c|c|}
\hline & & Tropical & $N$ & MAP & Elevation & $\mathrm{D}$ & PS & $\mathrm{H}$ & $\mathrm{S}$ & Notes \\
\hline \multirow[t]{8}{*}{ Forests } & \multirow[t]{4}{*}{ Mountain } & Arusha NP & 1 & 1258 & 1653 & $\mathrm{U}$ & $\mathrm{NP}$ & - & 1 & Old-growth, $\geq 15 \mathrm{~m}$ high, plants dense \\
\hline & & Kasigau & 22 & $938 \pm 157$ & $1087 \pm 263$ & DD & Not $^{a}$ & 22 & - & $\begin{array}{l}\text { Old-growth, height varies among plots } \\
\text { ( } 8 \text { up to } 53 \mathrm{~m} \text { ), open canopy }\end{array}$ \\
\hline & & Taita Hills & 58 & $1215 \pm 45$ & $1696 \pm 145$ & DD & Not & 58 & - & $\begin{array}{l}\text { Old-growth, height (and density) varies } \\
\text { among plots }\end{array}$ \\
\hline & & Udzungwa & 4 & 1513 & $819 \pm 56$ & $U$ & NP & 4 & 3 & Old-growth \\
\hline & \multirow[t]{4}{*}{ Lowland } & Magombera & 6 & 1521 & $280 \pm 11$ & $\mathrm{D}$ & $\mathrm{GA}^{\mathrm{b}}$ & 6 & 6 & Old-growth \\
\hline & & River Forest & 1 & 660 & 687 & $\mathrm{D}$ & Not & - & 1 & $\begin{array}{l}\text { Old-growth, dense, small forest belt along } \\
\text { river; used for honey production }\end{array}$ \\
\hline & & Ukuguru & 4 & $1693 \pm 5$ & $313 \pm 49$ & $\mathrm{D}$ & $\mathrm{FR}^{\mathrm{c}}$ & 4 & - & Old-growth \\
\hline & & Mbudya & 1 & - & 9 & $\mathrm{D}$ & MR & 1 & - & Old-growth \\
\hline \multirow[t]{2}{*}{ Woodland } & Ukuguru & 3 & $1038 \pm 62$ & $561 \pm 71$ & $\mathrm{D}$ & Not & 3 & 1 & $\begin{array}{l}10 \text { to } 20 \mathrm{~m} \text { high with grass and/or } \\
\text { shrub undergrowth; open canopy }\end{array}$ & \\
\hline & SUA & 4 & $1034 \pm 13$ & $416 \pm 19$ & $\mathrm{D}$ & $\mathrm{FR}^{\mathrm{d}}$ & 4 & 3 & $\begin{array}{l}\leq 12 \mathrm{~m} \text { high with high dense grass, } \\
\text { trees scattered }\end{array}$ & \\
\hline \multirow[t]{2}{*}{ Bushland } & Ukuguru & 1 & 988 & 560 & $\mathrm{D}$ & Not & 1 & 1 & 4 to $5 \mathrm{~m}$ high, plants dense & \\
\hline & SUA & 4 & $1018 \pm 29$ & $377 \pm 43$ & $\mathrm{D}$ & $\mathrm{FR}^{\mathrm{d}}$ & 4 & 4 & $\begin{array}{l}\leq 5 \text { m high, very open } \\
\text { (plants scattered) }\end{array}$ & \\
\hline \multirow[t]{12}{*}{ Cultivated } & \multirow[t]{6}{*}{ Crops } & Banana & 2 & $1156 \pm 35$ & $49 \pm 56$ & - & - & 2 & 2 & $\begin{array}{l}\text { One young stand: } 4 \mathrm{~m} \text { high, one mature } \\
\text { stand: } 6 \mathrm{~m} \text { high; both dense }\end{array}$ \\
\hline & & Corn & 6 & $1133 \pm 250$ & $810 \pm 627$ & - & - & 3 & 4 & $\begin{array}{l}\text { mature stands with fruits (one } \\
\text { senescent); } \leq 2 \mathrm{~m}\end{array}$ \\
\hline & & Mbaazi & 1 & 988 & 562 & - & - & 1 & 1 & Young stand, $1-2 \mathrm{~m}$ high, plants scattered \\
\hline & & Rice & 1 & 1493 & 262 & - & - & 1 & 1 & Mature stand, $\geq 2 \mathrm{~m}$ high, very dense \\
\hline & & Sisal & 1 & 660 & 691 & - & - & 0 & 1 & $\begin{array}{l}\text { Mature stand, } \leq 2 \mathrm{~m} \text { high, dense in } \\
\text { parallel rows }\end{array}$ \\
\hline & & Sugarcane & 1 & 1493 & 256 & - & - & 1 & 1 & Mature stand, $\geq 2 \mathrm{~m}$ high, very dense \\
\hline & \multirow[t]{6}{*}{ Plantation } & Eucalyptus & 1 & 1097 & 963 & - & - & 1 & 1 & $\begin{array}{l}\text { Young stand, trees } 15 \text { to } 16 \mathrm{~m} \text { high, } \\
\text { plants dense }\end{array}$ \\
\hline & & Kigeria & 1 & 1499 & 261 & - & - & 1 & 1 & Very young stand, $4 \mathrm{~m}$ high, plants dense \\
\hline & & Lucia & 1 & 957 & 479 & - & - & 1 & 1 & $\begin{array}{l}\text { Mature stand, } 10 \text { to } 15 \mathrm{~m} \text { high, plants } \\
\text { scattered (canopy gaps) }\end{array}$ \\
\hline & & Mango & 1 & 994 & 542 & - & - & 1 & 1 & Young stand, 5-6 m high, plants scattered \\
\hline & & Palm & 4 & $1117 \pm 74$ & $185 \pm 229$ & - & - & 4 & 1 & $\begin{array}{l}\text { mature coconut stands; scattered, } \geq 15 \mathrm{~m} \\
\text { high except for one ( } 10 \mathrm{~m} \text { high) }\end{array}$ \\
\hline & & Pine & 1 & 1282 & 1921 & - & - & 1 & - & Mature stand, $\leq 50 \mathrm{~m}$ high \\
\hline
\end{tabular}

a Kasigau Forest Reserve nearby.

b Within boundaries of Selous Game Reserve.

c Kimboza Forest Reserve.

d Kitulanghalo Forest Reserve.

traits at the spatial resolution of satellite pixels (Fig. 3). SunScan measurements and hemispherical images were taken at least at nine sampling points $\left(\mathrm{S}_{\mathrm{i}}\right)$ distributed within plots established according to VALERI design whenever possible. In some biomes, due to terrain or accessibility, measurements were taken along linear south-to-north transects with GPS coordinates noted at each $\mathrm{S}_{\mathrm{i}}$. Plots or transects were usually placed within biomes at more than $50 \mathrm{~m}$ distance from the biome edge (except for some croplands). We took three SunScan
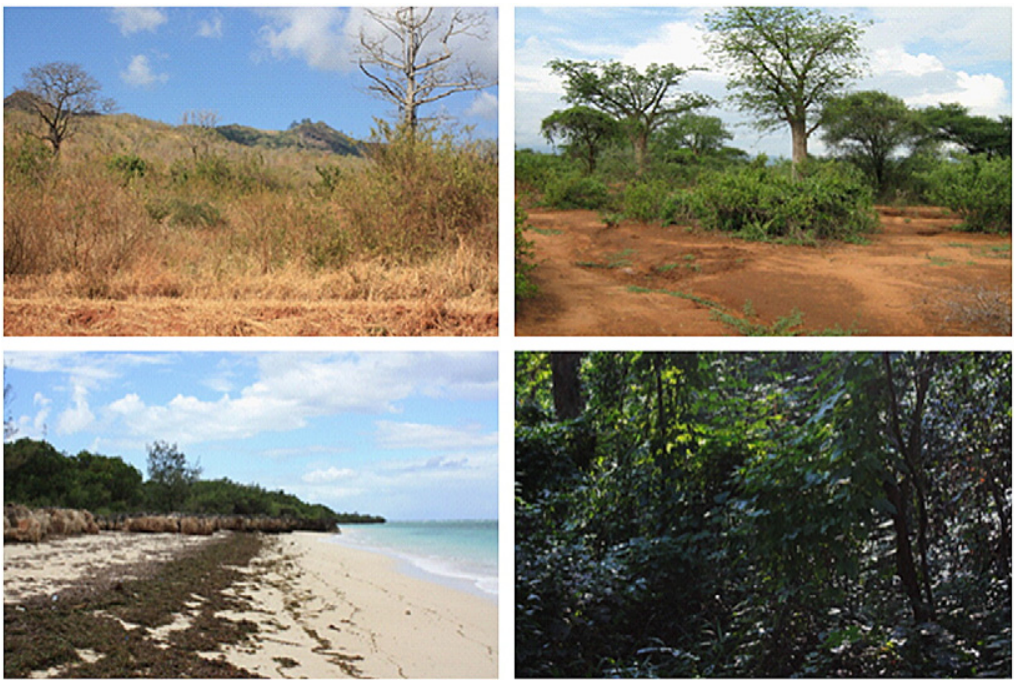
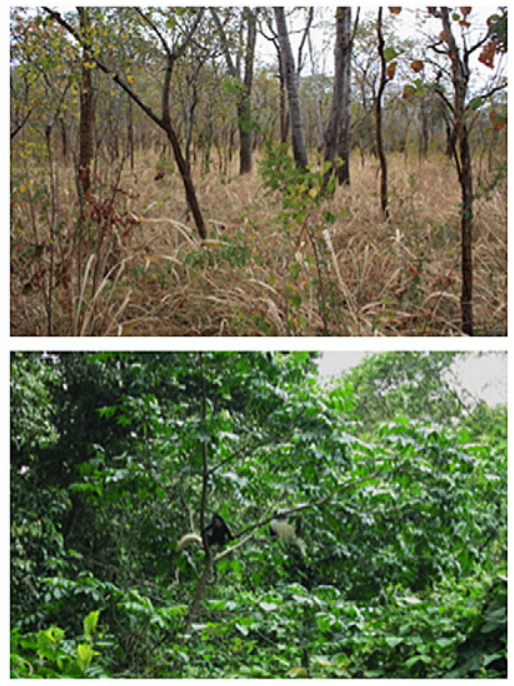

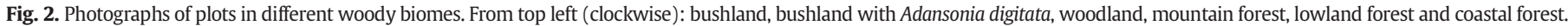


Table 2

Dates and locations for ground-based LAI measurements. SunScan (Delta-T Devices Ltd., Cambridge) and three camera systems were used. Camera System 1: a 12.3 megapixels Nikon D5000 SLR digital camera equipped with a Sigma $4.5 \mathrm{~mm}$ F2.8 fish-eye lens adapter; Camera System 2: a 8 megapixels Nikon Coolpix 8800 VR digital camera equipped with a fish-eye Nikon FC-E9 lens adapter; Camera System 3: Pictures in southern and coastal areas of Tanzania were taken with a 12.2 megapixels Canon EOS 450D equipped with a Sigma 4.5 mm F2.8 fish-eye lens adapter. For details on locations see Fig. 1.

\begin{tabular}{lll}
\hline Method & Dates & Locations \\
\hline SunScan & $03 / 01$ to $16 / 01 / 10$ and & $\begin{array}{l}\text { Amboselie, Arusha, Pare, } \\
\text { South Tanzania and coastal } \\
\text { sites near Dar es Salaam }\end{array}$ \\
& & Taita Hills \\
Camera System 1 & $26 / 01$ to $08 / 02 / 07$ & Kasigau \\
Camera System 2 & $14 / 01$ to $17 / 01 / 10$ & South Tanzania and coastal \\
Camera System 3 & $04 / 07$ to $19 / 07 / 10$ & sites near Dar es Salaam \\
\hline
\end{tabular}

readings per $S_{i}$ from three different directions. We collected one hemispherical image per $\mathrm{S}_{\mathrm{i}}$. Our sampling scheme aimed to capture heterogeneity in vegetation canopy structure. Thus, plot size was larger in forests, characterised by higher plants and more variable canopies (on the scale of satellite pixel resolution). However, canopies of dry woodlands and bushlands did not differ particularly over large distances, thus plot sizes were smaller.

\subsection{Hemispherical image processing}

After downloading from the camera system, each image was preprocessed (Fig. 3). The pixel brightness values for the blue band were extracted from each RGB image to achieve maximum contrast between leaf and sky, because absorption of leafy materials is maximal and sky scattering tends to be highest in that band (Jacquemoud \& Baret, 1990; Jonckheere et al., 2005b). Certain sky conditions can complicate classification of image pixels into vegetation and non-vegetation, e.g. sunflecks and dark clouds. Ways of establishing thresholds have been developed in order to avoid subjective decisions by the user and to identify the optimal brightness threshold to distinguish vegetation from sky (Jonckheere et al., 2005b). We used the most commonly applied global Ridler \& Calvard method for establishing the threshold in each image (Ridler \& Calvard, 1978), because of reliable results in hemispherical photography studies (Gonsamo \& Pellikka, 2008; Jonckheere et al., 2005a). Blue band extraction and threshold calculation followed an in-house developed C-shell script (Remote Sensing Unit, University College London).
The resulting binary images were analysed using the canopy analysis software CAN-EYE V6 (Weiss \& Baret, 2010: http://www.paca. inra.fr/can_eye) limiting the field of view of the lens to values between 0 and $60^{\circ}$ to avoid mixed pixels and thus misclassifications. CAN-EYE estimates mean effective LAI ( $\mathrm{LAI}_{\mathrm{EFF}}$ ) for each plot assuming spatially random distribution of foliage elements based on a series of (at least 9) images from measured gap fraction (Weiss \& Baret, 2010). $\mathrm{LAI}_{\mathrm{EFF}}$ is derived by inversion of the Poisson model using look-up tables and assuming an ellipsoidal distribution of leaf inclination (Weiss et al., 2000). A clumping index is computed using the Lang and Yueqin (1986) logarithm gap fraction averaging method and used in the modified Poisson model, which is then inverted to estimate $\mathrm{LAI}_{\mathrm{TRUE}}$, the LAI taking into account canopy clumping. Note that estimated $\mathrm{LAI}_{\mathrm{TRUE}}$ does include materials such as stems, trunks, branches, twigs and plant reproductive parts and may more accurately be called plant area index (Breda, 2003). Privette et al. (2002) report that LAI may be derived from plant area index by subtracting a so-called stem-area index (American biomes: 0.3 to 0.4 ). Note though that during the growing season of deciduous vegetation or in evergreen forest, the total vegetation surface itself is mainly composed of leaf area, and by a lesser part of twigs, branches and stem surface (Gonsamo, 2009). Fournier et al. (1996) also suggested that branches and boles contributed to total LAI by less than $5 \%$ in three relatively dense stands of conifers.

\subsection{Modelling relationships between LAI and spectral vegetation indices}

Satellite measurements for individual plots were derived from Landsat Enhanced Thematic Mapper (ETM +) and Système Probatoire d'Observation de la Terre (SPOT) 4/5 images (level 2a). The ETM + data was Level 1 terrain corrected images (L1T, resolution $=30 \mathrm{~m}$ ) obtained from the US Geological Survey's Earth Resources Observation and Science (EROS). The L1T ETM + products provide systematic radiometric and geometric accuracy by incorporating ground control points while employing a digital elevation model for topographic accuracy. SPOT images were provided by European Space Agency and SPOT IMAGE S.A., France. We selected cloud free satellite images that were nearly or completely free from haze. SPOT images were geo-referenced using ground-control points. We chose ETM + over SPOT if both were available for the same site because of the higher geolocation accuracy of $\mathrm{ETM}+$ data (see S1 in Supporting information). ENVI image analysis software (ITT Visual Information Solutions) was used for image processing and reflectance data extraction.

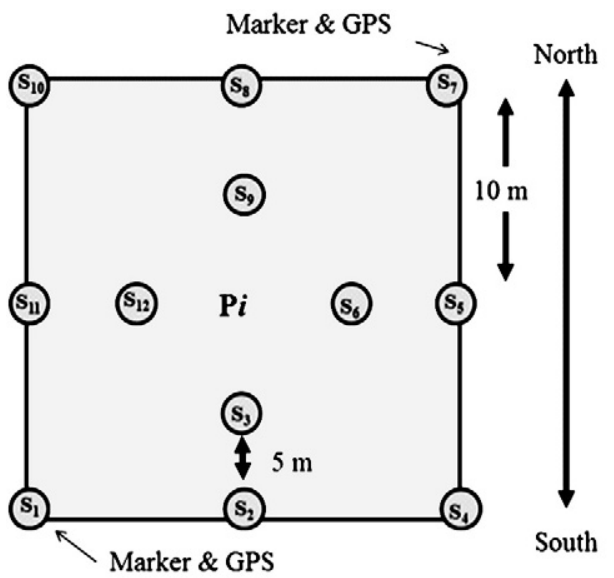

\section{Image processing}

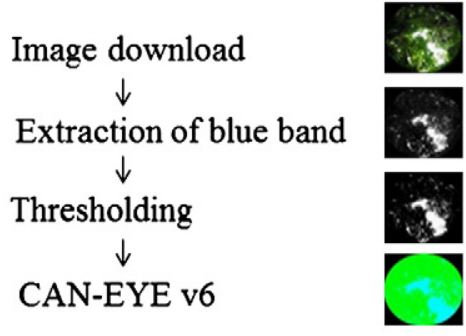

- Vegetation versus non-vegetation

- LAI based on gap fraction

- Plot estimates: $\geq 8$ images

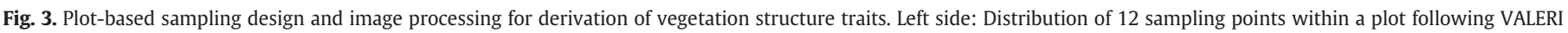

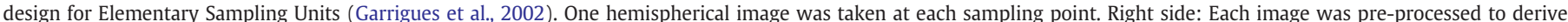

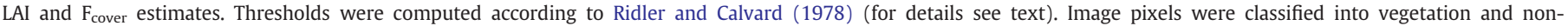

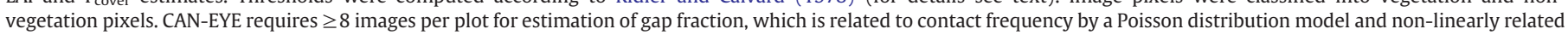
to LAI (Nilson, 1971). CAN-EYE settings: $2.5^{\circ}$ zenith angular resolution, $2.5^{\circ}$ azimuth angular resolution, $60^{\circ}$ circle of interest, $0-10^{\circ}$ integration domain for $\mathrm{F}_{\text {cover }}$. 
Atmospheric correction was carried out to estimate at-surface reflectance accounting for atmospheric effects (e.g. water vapour and aerosol impacts) employing the ENVI module FLAASH. Satellite images were subjected to radiometric calibration using band-specific gain and offset values (extracted from the metadata file accompanying each image) to produce radiance band-interleaved-by-line images. A scale factor was applied to ensure radiance data used as input for FLAASH were in units of $\mu \mathrm{W} /\left(\mathrm{cm}^{2} * \mathrm{~nm} * \mathrm{sr}\right)$. After entering information on sensor and scene (e.g. ground elevation of scene, flight date and times), we set the MODTRAN model atmosphere to 'tropical', the MODTRAN aerosol model to 'tropospheric' and initial visibility to 'clear (40 to $100 \mathrm{~km}$ )'.

We extracted information of satellite reflectance pixels closest to the individual plots. In addition to the geolocation of satellite pixels to the ground plot GPS measurements, each plot was also individually referenced on the satellite image via visual inspection to ensure its location within the biome was correct. While this is true for all natural vegetation type plots (forests, woodlands, bushlands), this may not apply for croplands and forest plantations, which were generally small in size and thus more difficult to locate exactly. In the latter case, we relied on geo-locating the ground plot GPS measurements to the corresponding satellite pixels.

In the first approach, hereafter referred to as 'one-month' approach, we only used plots for which satellite reflectance measurements could be obtained within a month - before or after - the date of ground measurements assuming that vegetation cover did not change within that period. This was done because LAI varies with season, especially in deciduous woodlands and bushland, and changes more drastically in croplands and plantations due to harvesting. Given the frequency of ETM + and SPOT image acquisition, it was found to be difficult to find cloud free images which coincided exactly to the ground measurement period for the entire ground measurement coverage. Therefore, in a second approach, hereafter referred to as 'six-month' approach, we evaluated the use of reflectance data obtained within six months of ground-based measurements thereby increasing plot coverage (see S2). Plots not covered with both approaches were excluded from further analysis.

While the normalised difference vegetation index (NDVI) is the predominantly used VI in ecological studies (Pettorelli et al., 2011), alternatives have been proposed to account for problems encountered when using simple near infrared (NIR)-red ratio. For example, the modified soil adjusted vegetation index (MSAVI2: Qi et al., 1994) has been developed to reduce soil noise whereas a series of 'enhanced' vegetation indices (EVI and EVI 2; Jiang et al., 2008) have been developed to reduce impacts of aerosol contamination on reflectances measured by the sensor. EVI has also been shown to be more sensitive to green leaf area index in crop fields and less prone to saturation in temperate and tropical forests compared to NDVI (Jiang et al., 2008).

We computed and used three VIs from at-surface reflectances in the red (SPOT: band2-0.61 to $0.68 \mu \mathrm{m}, \mathrm{ETM}+$ : band 3-0.631 to $0.692 \mu \mathrm{m}$ ) and near-infrared bands (SPOT: band 3-0.79 to $0.89 \mu \mathrm{m}$, ETM+: band 4-0.772 to $0.898 \mu \mathrm{m})$.

$\mathrm{NDVI}=(\mathrm{NIR}-\mathrm{RED}) /(\mathrm{NIR}+\mathrm{RED})$,

$\mathrm{EVI} 2=(\mathrm{G} *(\mathrm{NIR}-\mathrm{RED})) /(\mathrm{NIR}+\mathrm{C} * \mathrm{RED}+1)$,

MSAVI $2=\left((2 * \mathrm{NIR}+1)-\left((2 * \mathrm{NIR}+1)^{2}-8 *(\mathrm{NIR}-\mathrm{RED})\right)^{1 / 2}\right) / 2$

NIR, RED reflectances measured in the near-infrared and red part of the spectrum

G gain factor $\mathrm{G}$ (here set as $=2.5$ )

C coefficient of the aerosol resistance term (here set as $=2.4$ ).

\subsection{Statistical and sensitivity analysis}

All statistical analyses were carried out using the R 2.11.1 statistical software package. LAI and vegetation cover fraction $\left(\mathrm{F}_{\text {cover }}\right)$ were estimated for each plot. We calculated mean stand-specific estimates of LAI $I_{\text {TRUE }}, \mathrm{LAI}_{\mathrm{EFF}}$ and $\mathrm{F}_{\text {cover }}$ if more than one plot was sampled per stand (Tables 1 and 2). We computed mean biome specific LAI and $\mathrm{F}_{\text {cover }}$ ( \pm 1 standard deviation) from plot values, distinguishing between tropical forests (mountain, lowland and coastal), deciduous woodlands, bushland, croplands and tree plantations. We used ANOVA with multi-comparison post-hoc Tukey HSD tests to determine significant differences between group means, with regard to LAI. Analyses were carried out i) using LAI estimates derived from Camera System 3 (south and coastal Tanzania), and ii) including plots from Taita Hills and Kasigau measured with Camera Systems 1 and 2. We compared LAI estimates derived from hemispherical photography with LAI estimates derived using the SunScan instrument.

Plot co-ordinates and mean altitude above sea level were measured on the ground using a GARMIN GPSMAP 60 CSX handheld Global Positioning System device. For plots without elevation information, we used the ASTER global digital elevation model at $30 \mathrm{~m}$ spatial resolution (https://wist.echo.nasa.gov/ wist/api/imswelcome/) to derive plot altitude. Mean annual precipitation (MAP) for each plot was extracted from the WORLDCLIM dataset, which provides long-term climatic averages for precipitation compiled from weather station data between 1960 and 1990 at $1 \mathrm{~km}$ grid resolution (Hijmans et al., 2005).

We tested for significant relationships between MAP and vegetation canopy traits using linear models assuming increasing LAI with increasing MAP due to long-term adaption of biomes to their environment (e.g. expecting productivity to be precipitation-constrained). We classified MAP into six classes $(\leq 400 \mathrm{~mm}, 400-699 \mathrm{~mm}, 700-999 \mathrm{~mm}$, $1000-1299 \mathrm{~mm}, 1300-1699 \mathrm{~mm}$ and $\geq 1700 \mathrm{~mm}$ ) and altitude into six classes $\quad(0-199 \mathrm{~m}, \quad 200-599 \mathrm{~m}, \quad 600-999 \mathrm{~m}, \quad 1000-1399 \mathrm{~m}$, $1400-1799 \mathrm{~m}$ and $\geq 1800 \mathrm{~m}$ above sea level). We tested for significant differences between forests at different classes of altitude and precipitation regarding $\mathrm{LAI}_{\mathrm{TRUE}}$ using ANOVA ( $6 \times 6$ factorial design) with posthoc Tukey HSD tests.

We computed linear and non-linear regression models with VIs as predictor variables and LAI as the dependent variable. Model selection was based on best-fit using the 'goodness-of-fit' of the line $\left(R^{2}\right)$. We included MAP as an additional predictor variable in regression models to test whether this would significantly improve the capacity of the model to explain the variability of measured LAI (tested using ANOVA).

\section{Results}

\subsection{LAI across biomes in the Eastern Arc Mountains and their catchments}

Tropical forests had significantly higher LAI values compared to other biomes (ANOVA: $p<0.001$; Fig. 4 , Table 3). Differences in LAI between woodlands, bushlands, croplands and forest plantations were mostly not significant, although $\mathrm{LAI}_{\mathrm{TRUE}}$ was significantly lower in bushland compared to $\mathrm{LAI}_{\mathrm{TRUE}}$ of cropland and forest plantations (Table 4).

LAI of tropical forests in South Kenya (Taita Hills and Kasigau forests: mean $\mathrm{LAI}_{\mathrm{TRUE}}=2.14$ ), which show higher degree of disturbance, was significantly lower than LAI measured in tropical forests of Tanzania (mean LAI TRUE $=3.79$ ) (Wilcox test: $p<0.001$ ). When including plots from South Kenya in inter-comparisons of LAI between biomes, LAI of forests was significantly higher compared to bushlands $(p<0.001)$, plantations $(p<0.05)$ and woodlands $(p<0.05)$ but did not differ significantly from LAI measured in croplands.

$\mathrm{LAI}_{\text {SUN }}$ increased with LAI TRUE across plots in natural woody vegetation and most plots in cropland and plantations (Fig. 5). LAI TRUE followed a sigmoidal curve in response to LAI $_{\text {SUN }}$ plateauing around $\mathrm{LAI}_{\text {SUN }} \geq 5$. This implies that higher LAI, expected in dense forest stands, seems to be better captured by the SunScan instrument (Fig. 4). 

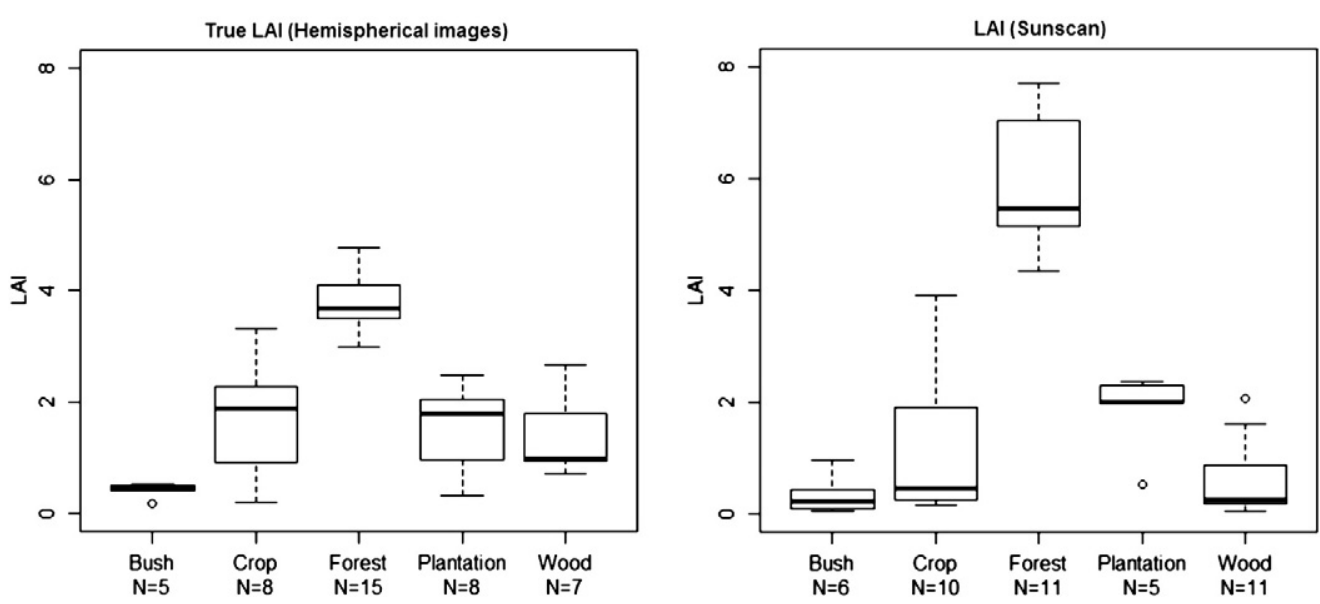

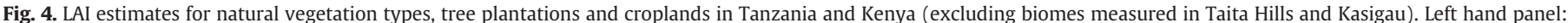

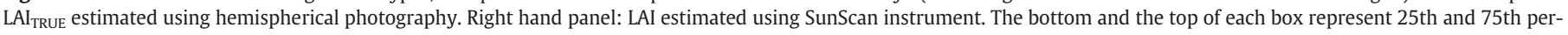

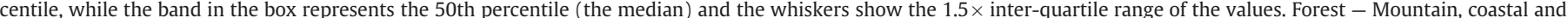
lowland forests; Wood - Tropical deciduous woodlands (Miombo); Bush - Tropical bushlands; Crop - Agricultural crops; Plantations - Tree plantations of different species.

Table 3

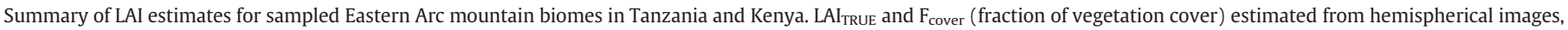

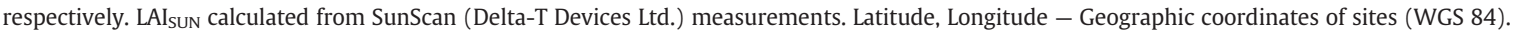

\begin{tabular}{|c|c|c|c|c|c|c|c|}
\hline & & Biome & Latitude & Longitude & $\mathrm{LAI}_{\mathrm{TRUE}}$ & $\mathrm{LAI}_{\text {SUN }}$ & $\mathrm{F}_{\text {cover }}$ \\
\hline \multirow[t]{8}{*}{ Forests } & \multirow[t]{4}{*}{ Mountain } & Arusha NP & -3.3 & 36.9 & - & 4.3 & - \\
\hline & & Kasigau & $-3.8 /-3.9$ & $38.6 / 38.7$ & $2.1 \pm 0.6$ & - & $54.8 \pm 18.6$ \\
\hline & & Taita Hills & $-3.4 /-3.5$ & 38.3 & $2.3 \pm 0.5$ & - & $53.6 \pm 12.4$ \\
\hline & & Udzungwa & -7.8 & 36.9 & $3.8 \pm 0.4$ & $7.0 \pm 0.9$ & $77.6 \pm 5.9$ \\
\hline & \multirow[t]{4}{*}{ Lowland } & Magombera & -7.8 & 37.0 & $3.5 \pm 0.3$ & $5.9 \pm 1.0$ & $80.5 \pm 8.0$ \\
\hline & & River forest & -4.4 & 37.8 & - & 5.0 & - \\
\hline & & Ukuguru & -7.0 & 37.8 & $4.4 \pm 0.4$ & - & $74.1 \pm 2.8$ \\
\hline & & Mbudya & -6.7 & 39.2 & 3.0 & - & 63.1 \\
\hline \multirow[t]{2}{*}{ Woodland } & Ukuguru & -6.9 & 37.7 & $1.7 \pm 0.9$ & 0.4 & $33.3 \pm 13.5$ & \\
\hline & SUA & -6.7 & 37.9 & $1.2 \pm 0.5$ & $1.2 \pm 1.1$ & $30.5 \pm 11.8$ & \\
\hline \multirow[t]{2}{*}{ Bushland } & SUA & -6.7 & 37.9 & $0.4 \pm 0.1$ & $0.2 \pm 0.1$ & $3.9 \pm 2.6$ & \\
\hline & Ukuguru & -6.9 & 37.7 & 0.52 & 0.95 & 11.7 & \\
\hline \multirow[t]{12}{*}{ Cultivated } & \multirow[t]{6}{*}{ Crops } & Banana & $-6.9 /-7.0$ & 39.4 & $2.3 \pm 1.5$ & 0.6 & $31.2 \pm 21.0$ \\
\hline & & Corn & Varies & Varies & $1.4 \pm 1.0$ & $0.8 \pm 1.1$ & $7.9 \pm 7.8$ \\
\hline & & Mbaazi & -6.8 & 37.8 & 0.6 & 0.2 & 6.9 \\
\hline & & Rice & -7.9 & 37.0 & 2.4 & 3.9 & 38.4 \\
\hline & & Sisal & -4.4 & 37.8 & - & 0.3 & - \\
\hline & & Sugarcane & -7.9 & 37.0 & 2.0 & 1.9 & 31.2 \\
\hline & \multirow[t]{6}{*}{ Plantation } & Eucalyptus & -6.8 & 37.8 & 1.5 & 2.3 & 32.8 \\
\hline & & Kigeria & -7.9 & 37.0 & 1.7 & 2.0 & 79 \\
\hline & & Lucia & -6.8 & 37.8 & 2.2 & 2.0 & 55 \\
\hline & & Mango & -6.8 & 37.8 & 1.88 & 2.4 & 15.8 \\
\hline & & Palm & Varies & Varies & $1.3 \pm 1.1$ & 0.5 & $23.8 \pm 20.8$ \\
\hline & & Pine & -3.4 & 38.3 & 1.3 & - & 40.1 \\
\hline
\end{tabular}

\subsection{LAI in relationship to precipitation and altitude}

LAI $_{\text {TRUE }}$ significantly increased with increasing MAP for woody biomes $\left(R_{\text {adj }}^{2}=0.39, p<0.001\right.$ ) (Fig. 6 ). Predictive quality of the LAI-MAP model increased when solely focussing on plots measured in Tanzania $\left(R_{\text {adj }}^{2}=0.87, p<0.001\right)$. Including cultivated land (croplands, plantations) decreased model fits. Although, that model fitted better when solely using the forest measurements in Tanzania $\left(R^{2}{ }_{\text {adj }}=0.62\right.$, $p<0.001$ ) compared to including South Kenya forests (Fig. 6).

Forests in Tanzania (higher LAI) were located at significantly lower altitudes ( $414 \pm 265 \mathrm{~m}$ asl) compared to forests in Kenya (lower LAI). Within Kenyan plots, forests in Kasigau $(1087 \pm 263 \mathrm{~m}$ asl) were found at significantly lower altitudes compared to forest plots in Taita Hills $\left(1696 \pm 145 \mathrm{~m}\right.$ asl), but, $\mathrm{LAI}_{\mathrm{TRUE}}$ did not differ significantly between them. However, ANOVA showed that altitude and precipitation contribute significantly to LAI variability among forests. Looking at both factors separately, forests with higher precipitation (1300-1699 mm, $>1700 \mathrm{~mm}$ ) had significantly higher $\mathrm{LAI}_{\mathrm{TRUE}}$ compared to all other forests (Fig. 6B). Forests located 200 to $599 \mathrm{~m}$ asl had significantly higher LAI values compared to all other plots (Fig. 6C). However, effects of altitude on LAI remain to be evaluated in further studies. Tanzanian

Table 4

Tukey'd HSD tests $p$-values for posthoc mean comparisons among biomes regarding $\mathrm{LAI}_{\text {SUNS }}, \mathrm{LAI}_{\mathrm{TRUE}}$ and $\mathrm{LAI}_{\mathrm{EFF}}$. $\mathrm{LAI}_{\text {SUNS }}$ - Plots measured with SunScan in 2010. LAI TRUE and $\mathrm{LAI}_{\mathrm{EFF}}$ - Plots with true and effective LAI estimates derived using hemispherical photography (excluding plots in Kasigau and Taita Hills). Only significant and marginally significant results $(p<0.05$ and $p<0.10)$ are shown. NS - not significant.

\begin{tabular}{llll}
\hline Paired biomes & LAI $_{\text {SUNS }}$ & $\mathrm{LAI}_{\text {TRUE }}$ & LAI $_{\text {EFF }}$ \\
\hline Evergreen forests $<>$ Woodland & 0.000 & 0.000 & 0.000 \\
Evergreen forests $<>$ Bushland & 0.000 & 0.000 & 0.000 \\
Evergreen forests $<>$ Cropland & 0.000 & 0.000 & 0.000 \\
Evergreen forests $\sim>$ Plantation & 0.000 & 0.000 & 0.000 \\
$\quad$ Savannah & & & \\
Cropland $<>$ Bushland & $\mathrm{NS}$ & 0.018 & 0.080 \\
Plantation $<>$ Bush & 0.098 & 0.048 & 0.087 \\
Woodland $<>$ Bush & $\mathrm{NS}$ & $\mathrm{NS}$ & 0.071 \\
\hline
\end{tabular}



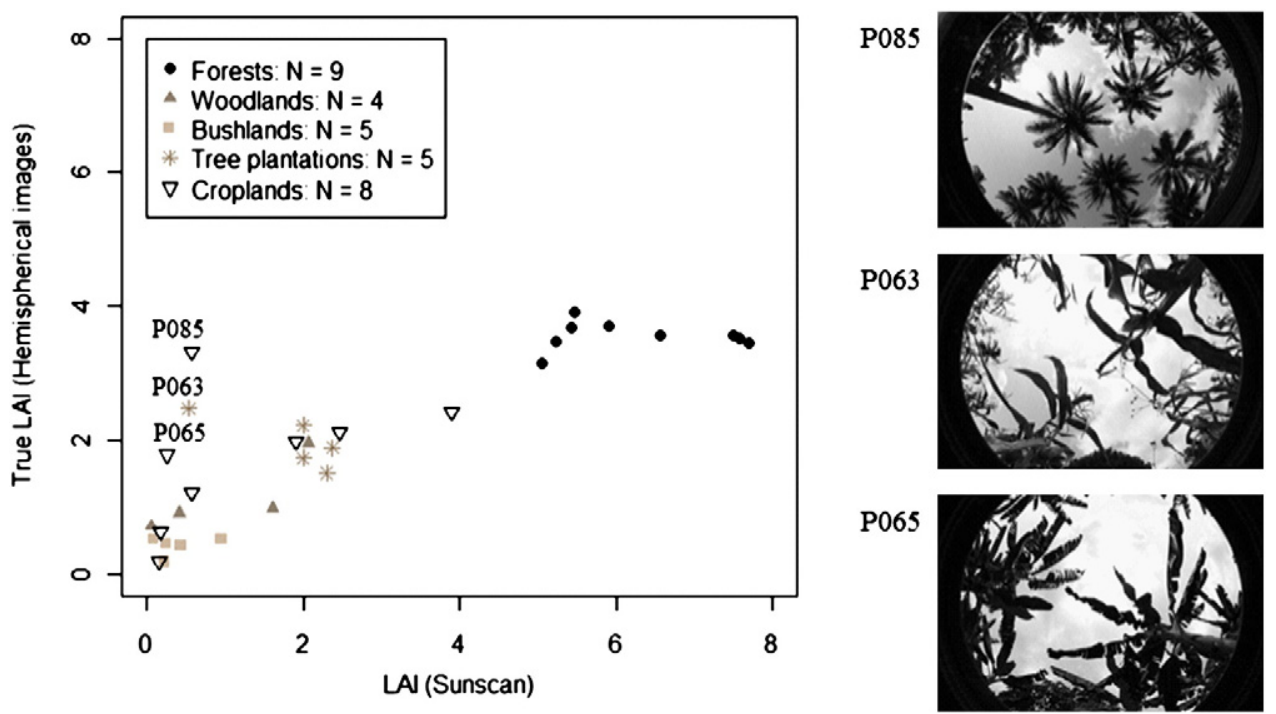

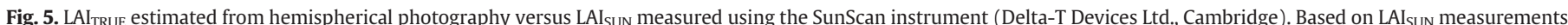

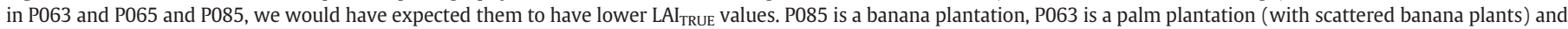

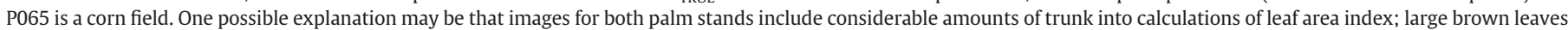
of relatively dense standing corn plants may artificially increase LAI measured by hemispherical photography in the corn field.

bushlands and woodlands showed lower $\mathrm{LAI}_{\mathrm{TRUE}}$ compared to Kenyan forests despite being located in higher precipitation environments. On the other hand, Kenyan forests were found at much higher altitudes compared to bushlands and woodlands (Table 1).

\subsection{Relationships between LAI-Spectral indices}

Models using satellite reflectances collected within one month of ground based measurements were based solely on ETM + data (see S1). LAI showed a highly significant relationship with all three VIs (Table 5). $\mathrm{LAI}_{\text {TRUE }}$ followed an exponential curve in response to EVI 2 when excluding South Kenya plots, but the $\mathrm{LAI}_{\mathrm{TRUE}}-\mathrm{EVI} 2$ relationship was linear when including these forests (Fig. 7). LAI TRUE showed significant linear relationships with NDVI and MSAVI2 (Table 5; see also S3 for LAI map derived from NDVI measurements).

Model fits decreased considerably when using the 'six-month' approach (with South Kenya plots: $R^{2}=0.30$, linear model: $\mathrm{LAI}=0.62+$ EVI $2 * 1.11, N=64$; without South Kenya plots: $R^{2}=0.48$, linear model: $\mathrm{LAI}=0.08+$ EVI $2 * 1.61, N=36$ ) (see S4 in Supporting information). When solely using natural woody biomes in this 'six-month' approach, model fits where similar to the 'one-month' approach (with South Kenya forests: $R^{2}=0.40$, linear model: $\mathrm{LAI}=-0.12+\mathrm{EVI} 2 * 1.54$,
A

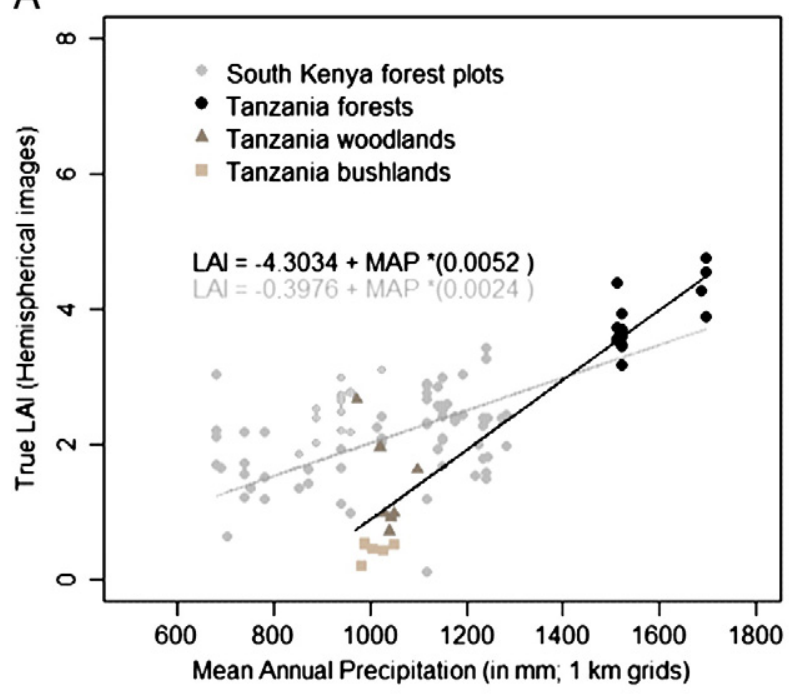

B

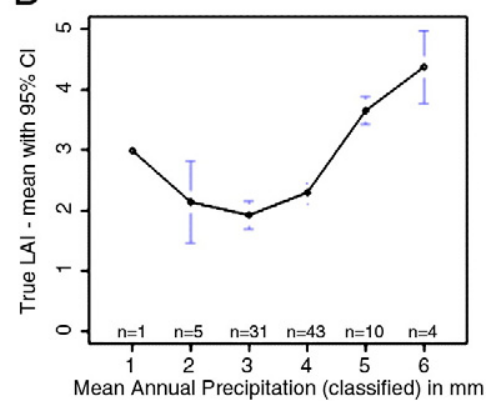

C

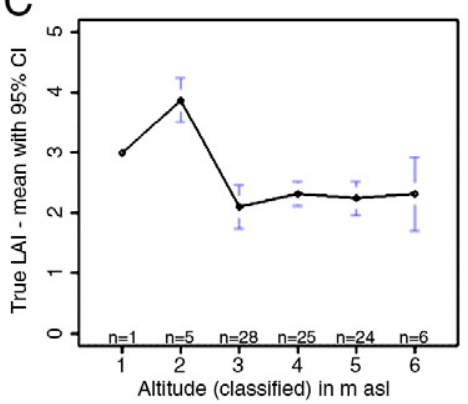

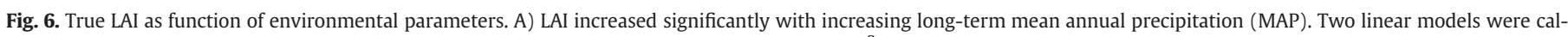

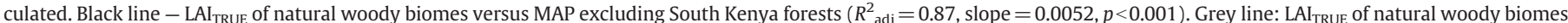

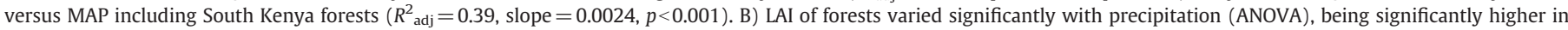

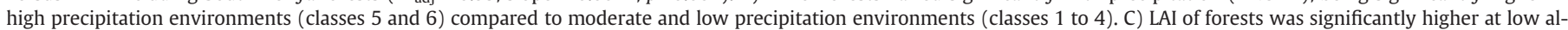
titudes (class 2: 200-599 $\mathrm{m}$ asl) compared to very low and high altitudes. 
Table 5

Summary of regression models for LAI versus spectral vegetation indices derived using spectral reflectances collected within one month of ground measurements. Grey: including all plots. Black: excluding plots in Kasigau and Taita Hills. LAI TRUE - estimates

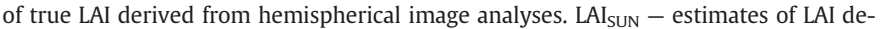
rived using the Sunscan-Delta-T device.

\begin{tabular}{clllll}
\hline & Type & Model & $R^{2}$ & $P$ & $N$ \\
\hline LAI $_{\text {TRUE }} \sim \mathrm{EVI} 2$ & Linear & $\mathrm{LAI}=-0.08+\mathrm{EVI} 2 * 1.52$ & 0.45 & $* * *$ & 52 \\
& Exponential & $\mathrm{LAI}=\mathrm{EVI} 2^{\wedge}(1.837 \pm 0.064)$ & 0.80 & $* * *$ & 28 \\
$\mathrm{LAI}_{\text {SUN }} \sim \mathrm{EVI} 2$ & Exponential & $\mathrm{LAI}=\mathrm{EVI} 2^{\wedge}(2.534 \pm 0.077)$ & 0.87 & $* * *$ & 24 \\
Savannah & & & & & \\
$\mathrm{LAI}_{\text {TRUE }} \sim \mathrm{NDVI}$ & Linear & $\mathrm{LAI}=-0.85+\mathrm{NDVI} * 4.35$ & 0.45 & $* * *$ & 52 \\
& Linear & $\mathrm{LAI}=-2.49+\mathrm{NDVI} * 6.91$ & 0.78 & $* * *$ & 28 \\
$\mathrm{LAI}_{\text {SUN }} \sim \mathrm{NDVI}$ & Linear & $\mathrm{LAI}=-4.88+\mathrm{NDVI} * 11.66$ & 0.71 & $* * *$ & 24 \\
$\mathrm{LAI}_{\text {TRUE }} \sim \mathrm{MSAVI} 2$ & Linear & $\mathrm{LAI}=2.55+\mathrm{MSAVI} 2 * 5.86$ & 0.43 & $* * *$ & 52 \\
& Linear & $\mathrm{LAI}=-5.28+\mathrm{MSAVI} 2 * 9.42$ & 0.76 & $* * *$ & 28 \\
$\mathrm{LAI}_{\text {SUN }} \sim \mathrm{MSAVI} 2$ & Linear & $\mathrm{LAI}=-8.04+\mathrm{MSAVI} 2 * 14.00$ & 0.62 & $* * *$ & 24 \\
\hline
\end{tabular}

$N=50$; excluding South Kenya forests: $R^{2}=0.80$, exponential model: $\left.\mathrm{LAI}=\mathrm{EVI} 2^{\wedge}(1.841 \pm 0.064), N=23\right)$.

Implementing long-term mean annual precipitation as second predictor variable into the VI-LAI models ('one-month' approach) significantly improved model predictive capability especially when covering plots from both, Tanzania and Kenya (Table 6).

\section{Discussion}

4.1. Leaf area index across biomes in the Eastern Arc Mountains and catchment areas

Many ecosystem process models require an estimate of LAI and its response to environmental drivers such as light and precipitation (Borchers et al., 1995; Ryan et al., 1996). Mean LAI values of forests in the Eastern Arc Mountains and their catchment areas are similar to LAI estimates given for other forests in East Africa (Ribeiro, Saatchi, et al., 2008; Ribeiro, Shugart, et al., 2008) and worldwide (Asner et al., 2003). LAI decreased from forests to woodlands and bushlands, in line with Asner et al.'s (2003) and findings. However, differences among non-forest woody biomes are not or only marginally significant. The lesser discrepancy of LAI in non-forest woody biomes may probably be explained by varying degrees of disturbances (e.g. fire related, or human resource use) and management
Table 6

Summary of regression models for $\mathrm{LAI}_{\mathrm{TRUE}}$ as a function of spectral vegetation indices and mean annual precipitation (MAP) derived from WORLDCLIM datasets. Grey: including all plots. Black: excluding plots in Kasigau and Taita Hills. LAI $\mathrm{TRUE}_{\mathrm{T}}$ - estimates of true LAI derived from hemispherical image analyses.

\begin{tabular}{llll}
\hline & Model & $R^{2}$ & $P$ \\
\hline $\mathrm{LAI}_{\mathrm{TRUE}} \sim \mathrm{EVI} 2$ & $\mathrm{LAI}=-0.97+1.195 * \mathrm{EVI} 2+0.001 * \mathrm{MAP}$ & 0.51 & $* * *$ \\
& $\mathrm{MAP}$ not significant parameter & - & - \\
$\mathrm{LAI}_{\mathrm{TRUE}} \sim \mathrm{NDVI}$ & $\mathrm{LAI}=-1.70+3.436 * \mathrm{NDVI}+0.001 * \mathrm{MAP}$ & 0.52 & $* * *$ \\
& $\mathrm{LAI}=-3.20+4.910 * \mathrm{NDVI}+0.002 * \mathrm{MAP}$ & 0.81 & $* * *$ \\
$\mathrm{LAI}_{\mathrm{TRUE}} \sim \mathrm{MSAVI} 2$ & $\mathrm{LAI}=-3.18+4.630 * \mathrm{MSAVI} 2+0.001 * \mathrm{MAP}$ & 0.53 & $* * *$ \\
& $\mathrm{LAI}=-5.20+6.265 * \mathrm{MSAVI} 2+0.002 * \mathrm{MAP}$ & 0.80 & $* * *$ \\
\hline
\end{tabular}

differences causing a transient nature of boundaries between them (Bond et al., 2005).

Spatial variation in vegetation canopy structure in East Africa is shaped by complex interactions between environmental parameters, including precipitation (Bucini \& Hanan, 2007), land use (e.g. pole-cutting, charcoal production; Chidumayo \& Kwibisa, 2003) and fire (Ribeiro, Shugart, et al., 2008; Archibald et al., 2010). Observed lower LAI values of the more disturbed forests in Taita Hills (southern Kenya) compared to Tanzania are possible evidence of the negative impacts of forest degradation on ecosystem function (Nepstad et al., 2008). Topography at Kasigau Mountain (bare rock and steep slopes are frequent) may contribute to lower LAI observed in forests located there.

There are confounding factors rooted in technical limitations. Complex vegetation patterns where dense vegetation alternates periodically with sparsely populated or bare soil can cause unpredictable errors in the quantification of biophysical properties of the vegetation (Hufkens et al., 2008). For example large, high-biomass Adansonia digitata trees are scattered throughout otherwise low-biomass bushland, thereby locally increasing LAI and introducing bias in biome-specific LAI estimates. Including measures of vegetation cover composition and vegetation coverage could reduce these errors for systematic assessments of mean LAI values per biome.

LAI of croplands and forest plantations is comparable to LAI of woodlands and bushlands, which may relate to their predominance in similar precipitation environments. However, LAI is very variable among crops and forest plantations, which may probably be attributed to crop type, plantation forest age, crop management and local growth conditions especially with regard to water supply (Amiri \& Asil, 2007; Lindquist et al.,
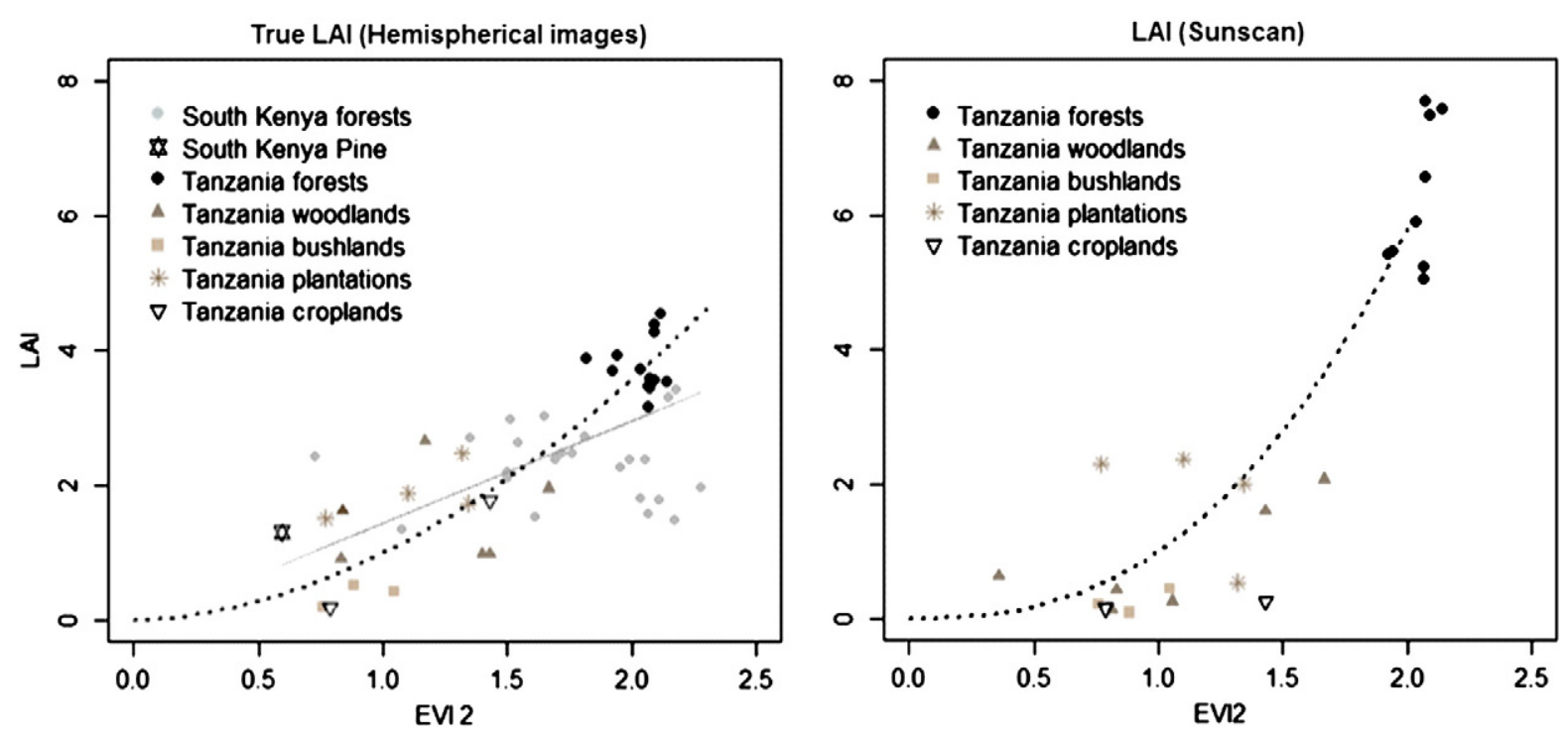

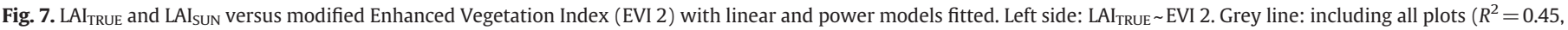

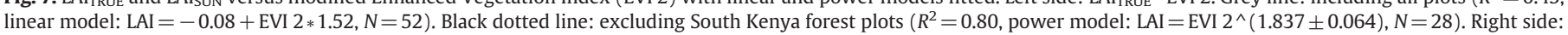
$\mathrm{LAI}_{\text {SUN }} \sim \mathrm{EVI} 2$ with fitted power model $\left(R^{2}=0.87, \mathrm{LAI}=\mathrm{EVI} 2^{\wedge}(2.534 \pm 0.075), N=24\right) . \mathrm{TZ}-$ Tanzania. 
2005; Palmer et al., 2005; Whitehead \& Beadle, 2004), while effects of crop maturity may be less important in this study since most crops measured are mature stands (Table 1). However, it is important to note that sample number was very low in most crop stands; to derive more generalising conclusions regarding LAI variability in crop stands would require measurements in additional plots accounting for different water supply and management.

Note that LAI seasonality is not directly relevant in this study, because all Tanzanian LAI $_{\text {TRUE }}$ estimates were derived for the dry season in July 2010 and are thus directly comparable. However, LAI seasonality is an important factor for assessing intra-annual LAI and biomass fluctuations (van Scheik et al., 1993; Borchert et al., 2002; Myneni et al., 2007; Kalácska et al., 2005). In situ LAI measurements could be carried out during dry and wet seasons to develop season-specific LAI-VI models (Malhado et al., 2009; Wasseige et al., 2003), as is currently done by a new research project (WWF Tanzania REDD +).

Aragão et al. (2005) showed how precision of LAI estimates for Eastern Amazon landscape units could be increased by including landscape variables such as land cover, land use and terrain features. While our dataset is limited regarding coverage of different forest altitudes, our results may indicate that forests at lower altitudes have higher LAI than forests in mid- to high-altitudinal ranges. LAI increases with increasing MAP in our study area. It would be worthwhile to consistently measure LAI of woody biomes along an altitudinal gradient of high mountains in East Africa to test for an expected hump-shaped response curve, with LAI being precipitation limited at very low altitudes, and temperature limited at very high altitudes.

\subsection{Leaf area index-VI relationships across East Africa}

Despite the complexity of canopy structure changes across large spatial scales, our results indicate that SPOT and ETM + derived VI in combination with information about the long-term MAP may be a suitable tool to develop landscape maps of LAI in Eastern Africa.

Empirical relationships between spectral VIs and LAI lack a physical basis. However, all three indices used here correlated significantly with LAI, and models differed only slightly in their predictive quality. The two-band EVI 2 outperformed NDVI and MSAVI2 in producing highly significant models of LAI-VI relationships. However, this was only when solely focussing on plots measured in Tanzania in 2010 using the SunScan instrument. Note that the number of plots sampled with the SunScan instrument has been low. This will be addressed in future studies.

Model fit decreased when measuring across larger distances compared to models developed specifically for Tanzania. This large-scale spatial variation in model capabilities will introduce errors in VI based LAI maps for Eastern Africa. Asner et al. (2010) found significant variation of standing carbon stock and forest structure in Amazon forests across 4.3 million ha mediated by geological substrate, forest type and soil water content as well anthropogenic disturbances. In our study, including MAP as additional predictor variable improved model fit by nearly $10 \%$, resulting in models that could explain more than $50 \%$ of the variation in LAI across Eastern Africa. Whether this accuracy is sufficient will probably depend on the questions of subsequent analyses. Disturbance frequency and species identity may be key players, which when included in such models, may further increase the models' predictive capabilities. This would require measuring LAI in additional plots, set up within a stratified random sampling design characterised by combinations of various levels of potential drivers of canopy structure within man-made and natural biomes.

Results from the 'six-month' approach underline the importance of accounting for LAI seasonality when developing VI-based LAI maps, especially when working on cultivated lands and in woody biomes with strong, climate-induced seasonal patterns.

\subsection{Implications and challenges}

Increasing land demands in the Eastern Arc Mountains and their catchment areas are threatening not only biodiversity, but also ecosystem processes and services usually associated with these forests, including carbon sequestration, soil protection, and catchment hydrology (Burgess et al., 2007; Burgess et al., 2010). Predicting changes in these services in relation to land use, e.g. by employing ecosystem process models, is the base for developing sustainable, disturbance mitigating management plans (Raupach et al., 2005; Rumpff et al., 2011). Constraining models with LAI estimates measured on the ground, as done in this study, could be important to derive more 'realistic' model predictions, which could then be linked to environmental and economic predictions.

Reducing uncertainties in model predictions requires data at sufficient spatial resolution (e.g. capturing patterns in fragmented and heterogeneous landscapes when working at regional scales) to constrain models (Chiesi et al., 2002). Upscaling ecological trait information from plot to landscape scale employing VIs can be improved using precipitation and, perhaps, topography. However, terrain topography (especially the degree of slope) can also affect LAI estimation on the ground due to technical caveats (Gonsamo \& Pellikka, 2008, 2009). And, the relative importance of contributing environmental factors to LAI variability varies spatially. Differences in tree density, structure and leaf optical properties between more or less evergreen forests and strictly deciduous woodlands may affect biome-specific LAI-VI relationships (Clark et al, 2008; Geiger et al., 2011; Kalácska et al., 2004; Lewis \& Disney, 2007). Including biome seasonality may improve model capabilities for up-scaling LAI across large areas (Pinto-Junior et al., 2011).

Hemispherical image analysis accounts for the discontinuous nature of many canopy stands by introducing a vegetation clumping index into the LAI estimation (Chen et al., 1997; Nilson, 1971). However, reflectance saturation at high LAI is a remaining challenge when using optical methods to estimate LAI (Myneni et al., 2007). Likewise, VIs are limited in their ability to capture LAI variation in high LAI vegetation, because the sensitivity of VIs to changes in canopy amount saturates asymptotically with increasing LAI up to values of 2-5 (Haboudane et al., 2004). The SunScan instrument appears to be able to detect LAI variation above the threshold of $\mathrm{LAI}=5$, although comparison with destructive measurements in the field would be required to support that conclusion. Both indirect approaches are likely to underestimate leaf area in highly productive environments. Variability in the three-dimensional distribution of LAI within canopies of old-growth rain forests may complicate LAI estimation on landscape scales (Clark et al., 2008).

Most Earth Observation (EO) derived global LAI products employ the inversion of radiative transfer models that simulate surface reflectances from canopy structure, soil and leaf optical properties to estimate LAI (Myneni et al., 1997; Weiss et al., 2000; reviewed in Pfeifer et al., in press). While such models are physically-based, the radiative transfer model approach can introduce uncertainties as different combinations of model parameters may correspond to almost identical spectra (Gonsamo, 2009). One next step from our analysis could be to generate regional LAI maps using our upscaling functions and to use those maps to validate global LAI products available at coarse spatial resolution (Chen et al., 2002). While these products have great potential for ecosystem studies on macro-ecological scales, they may be more uncertain for most tropical forests of Africa compared to northern latitudes, due to a lack of African grounds plots in validation networks such as VALERI, EOS validation core sites, FLUXNET, BELIMANIP, and CEOS-LPV (Baret et al., 2006; Friend et al., 2007; Garrigues et al., 2008). This study provides needed ground measurements for validation of global LAI products in Eastern Arc Mountain biomes.

\section{Conclusions}

Understanding biome-LAI relationships and their variation across landscape scales is essential for improving ecosystem process models. 
This is particularly true in East Africa, an under-represented region in global estimates of LAI. Here, we present measurements of LAI made across a number of key East African biomes including forests ( $\mathrm{LAI}_{\mathrm{TRUE}}$ across all forest plots: $2.40 \pm 0.85$; mean \pm sd), Miombo woodlands ( $1.40 \pm 0.71)$, bushland $(0.42 \pm 0.14)$ and crops (across crop categories: $1.71 \pm 0.70$ with a low number of samples per crop type), across a precipitation gradient. We relate field-measured LAI to satellite-derived vegetation indices, with associated uncertainty estimates, potentially allowing upscaling of spatially continuous data on vegetation structure to the regional level. Across all sites, evergreen forests are the biome with the highest LAI. However, the vegetation canopy structure of other woody biomes, including dry deciduous woodlands, savannahs and bushlands, is more transient. Precipitation may be a dominant driver of LAI variation within biomes. MAP was shown to explain 39\% (or when excluding disturbed Kenya forests from the model 87\%) of the increase of LAI across woody biomes. However, factors such as altitude and disturbance (e.g. in forests) may contribute further to LAI variation within biomes.

Including heterogeneity in landscape-scale drivers of canopy structure into LAI-VI models, e.g. as tested for precipitation, may be able to produce usable landscape maps of LAI, required in the context of current carbon mitigation activities in Tanzania. However, further studies are needed to disentangle the relative impact of abiotic and biotic factors on woody vegetation traits, which would require long-term monitoring to account for inter-seasonal and inter-annual fluctuations and experimental studies. This study provides invaluable ground measurements of LAI for global product validations and inputs for biome specific LAI values for ecosystem process models.

\section{Acknowledgements}

Marion Pfeifer is supported by the Marie Curie Intra-European fellowship IEF Programme (EU FP7-People-IEF-2008 Grant Agreement no. 234394). We acknowledge helpful assistance in the field from Simon Willcock at the University of Leeds. We thank the two anonymous reviewers for providing valuable comments on the manuscript. We are very grateful to the European Space Agency (ESA) and SPOT Image for providing SPOT satellite data used in this study (ESA principal investigator: category-1 proposal 6972). We thank the British Institute in Eastern Africa for logistic support.

\section{Appendix A. Supplementary data}

Supplementary data to this article can be found online at doi:10. 1016/j.rse.2011.11.009.

\section{References}

Aerts, R., Thijs, K. W., Lehouck, V., Beentje, H., Bytebier, B., Matthysen, E., Gulinck, H., Lens, L., \& Muys, B. (2011). Woody plant communities of isolated Afromontane cloud forests in Taita Hills, Kenya. Plant Ecology, 212, 639-649.

Ahrends, A., Burgess, N. D., Milledge, S. A. H., Bulling, M. T., Fisher, B., Smart, J. C. R. Clarke, G. P., Mhoro, B. E., \& Lewis, S. L. (2010). Predictable waves of sequential forest degradation and biodiversity loss spreading from an African city. Proceedings of the National Academy of Sciences of the United States of America, 107, 14556-14561.

Amer, K. H. (2010). Corn crop response under managing different irrigation and salinity levels. Agricultural Water Management, 97, 1553-1563.

Amiri, M. E., \& Asil, M. H. (2007). Determination of optimum harvestable length of shoots in tea (Camellia sinensis L.) based on the current shoot growth, rather than interval plucking. Journal of Food, Agriculture and Environment, 5, 122-124.

Anselmi, S., Chiesi, M., Giannini, A., Manes, F., \& Maselli, F. (2004). Estimation of Mediterranean forest transpiration and photosynthesis through the use of an ecosystem simulation model driven by remotely sensed data. Global Ecology and Biogeography, 13, 371-380.

Aragão, L. E. O. C., Shimabukuro, Y. E., Espinto Santo, D. B., \& Williams, M. (2005). Landscape pattern and spatial variability of leaf area index in Eastern Amazonia. Forest Ecology and Management, 211, 240-256.

Archibald, S., Nickless, A., Govender, N., Scholes, R. J., \& Lehsten, V. (2010). Climate and the inter-annual variability of fire in southern Africa: A meta-analysis using long-term field data and satellite-derived burnt area data. Global Ecology and Biogeography, 19, 794-809.

Asner, G. P., Powell, G. V. N., Mascaro, J., Knapp, D. E., Clark, J. K., Jacobson, J., et al. (2010). High-resolution forest carbon stocks and emissions in the Amazon.
Proceedings of the National Academy of Sciences of the United States of America, 107, 16738-16742.

Asner, G. P., Scurlock, J. M. O., \& Hicke, J. A. (2003). Global synthesis of leaf area index observations: Implications for ecological and remote sensing studies. Global Ecology and Biogeography, 12, 191-205.

Baret, F., Morisette, T. J., Fernandes, R. A., Champeaux, J. L., Myneni, R. B., Chen, J., et al. (2006). Evaluation of the representativeness of network of sites for the global validation and intercomparison of land biophysical products: Proposition of the CEOS-BELMANIP. IEEE Transactions on Geoscience and Remote Sensing, 44, 1794-1803.

Bjørndalen, J. E. (1992). Tanzania's vanishing rain forests - Assessment of nature conservation values, biodiversity and importance for water catchment. Agriculture, Ecosystems and Environment, 40, 313-334.

Bond, W. J., Midgley, G. F., \& Woodward, F. I. (2003). The importance of low atmospheric $\mathrm{CO}_{2}$ and fire in promoting the spread of grasslands and savannas. Global Change Biology, 9, 973-982.

Bond, W. J., Woodward, F. I., \& Midgley, G. F. (2005). The global distribution of ecosystems in a world without fire. New Phytologist, 165, 525-537.

Borchers, J., Chaney, J., Fisher, H., Fox, S., Haxeltine, A., Janetos, A., et al. (1995). Vegetation/ecosystem modeling and analysis project (VEMAP): Assessing biogeography and biogeochemistry models in a regional study of terrestrial ecosystem responses to climate change and $\mathrm{CO}_{2}$ doubling. Global Biogeochemical Cycles, 9, 407-437.

Borchert, R., Rivera, G., \& Hagnauer, W. (2002). Modification of vegetation phenology in a tropical semi-deciduous forest by abnormal drought and rain. Biotropica, 34, $27-39$.

Breda, N. J. J. (2003). Ground-based measurements of leaf area index: A review of methods, instruments and current controversies. Journal of Experimental Botany, 54, 2403-2417.

Bucini, G., \& Hanan, N. P. (2007). A continental-scale analysis of tree cover in African savannas. Global Ecology and Biogeography, 16, 593-605.

Burgess, N. D., Butynski, T. M., Cordeiro, N. J., Doggart, N. H., Fjeldsa, J., Howell, K. M., Kilahama, F. B., Loader, S. P., Lovett, J. C., Mbilinyi, B., Menegon, M., Moyer, D. C., Nashanda, E., Perkin, A., Rovero, F., Stanley, W. T., \& Stuart, S. N. (2007). The biological importance of the Eastern Arc Mountains of Tanzania and Kenya. Biological Conservation, 134, 209-231.

Burgess, N. D., Bahane, B., Clairs, T., Danielsen, F., Dalsgaard, S., Funder, M., et al. (2010). Getting ready for REDD + in Tanzania: A case study of progress and challenges. Oryx, 44, 339-351

Chen, J. M., \& Black, T. A. (1992). Defining leaf area index for non-flat leaves. Plant, Cell E' Environment, 15, 421-429.

Chen, J. M., Pavlic, G., Brown, L., Cihlar, J., Leblanc, S. G., White, H. P., et al. (2002). Derivation and validation of Canada-wide coarse-resolution leaf area index maps using high-resolution satellite imagery and ground measurements. Remote Sensing of Environment, 80, 165-184.

Chen, J. M., Rich, P. M., Gower, T. S., Norman, J. M., \& Plummer, S. (1997). Leaf area index on boreal forests: Theory, techniques and measurements. Journal of Geophysical Research, 102, 429-444.

Chidumayo, E. N., \& Kwibisa, L. (2003). Effects of deforestation on grass biomass and soil nutrient status in Miombo woodland, Zambia. Agriculture, Ecosystems and Environment, 96, 97-105.

Chiesi, M., Maselli, F., Bindi, M., Fibbi, L., Bonora, L., Raschi, A., Tognetti, R., Cermak, J., \& Nadezhdina, N. (2002). Calibration and application of FOREST-BGC in a Mediterranean area by the use of conventional and remote sensing data. Ecological Modelling, $154,251-262$.

Chiezey, U. F., Haruna, I. M., \& Odion, E. C. (2004). Growth and development of sorghum/soybean mixture with nitrogen, phosphorus and plant arrangement in the northern Guinea Savanna ecological zone of Nigeria. Crop Research, 28, 1-14.

Clark, D. B., Olivas, P. C., Oberbauer, S. F., Clark, D. A., \& Ryan, M. G. (2008). First direct landscape-scale measurement of tropical rain forest Leaf Area Index, a key driver of global primary productivity. Ecology Letters, 11, 163-172.

De Kauwe, M. G., Disney, M. I., Quaife, T., Lewis, P., \& Williams, M. (2011). An assessment of the MODIS 5 collection 5 leaf area index product for a region of mixed coniferous forest. Remote Sensing of Environment, 115, 767-780.

Doherty, R. M., Sitch, S., Smith, B., Lewis, S. L., \& Thornton, P. K. (2010). Implications of future climate and atmospheric $\mathrm{CO}_{2}$ content for regional biogeochemistry, biogeography and ecosystem services across East Africa. Global Change Biology, 16, 617-640.

Doraiswamy, P. C., Hatfield, J. L., Jackson, T. J., Akhmedov, B., Prueger, J., \& Stern, A. (2004). Crop condition and yield simulations using Landsat and MODIS. Remote Sensing of Environment, 92, 548-559.

Dovey, S. B., \& du Toit, B. (2006). Calibration of LAI-2000 canopy analyser with leaf area index in a young eucalypt stand. Trees-Structure and Function, 20, 273-277.

Du Toit, B., \& Dovey, S. B. (2005). Effect of site management on leaf area, early biomass development, and stand growth efficiency of a Eucalyptus grandis plantation in South Africa. Canadian Journal of Forest Research, 35, 891-900.

Fournier, R. A., Landry, R., August, N. M., Fedosejevs, G., \& Gauthier, R. P. (1996). Modelling light obstruction in tree conifer forests using hemispherical photography and fine tree architecture. Agricultural and Forest Meteorology, 82, 47-72.

Friend, A. D., Arneth, A., Kiang, N. Y., Lomas, M., Ogee, J., Rocdenbeckk, C., et al. (2007). FLUXNET and modelling the global carbon cycle. Global Change Biology, 13, $610-633$.

Furley, P. (2010). Tropical savannas: Biomass, plant ecology, and the role of fire on soil and vegetation. Progress in Physical Geography, 34, 563-585.

Garrigues, S., Allard, D., Weiss, M., \& Baret, F. (2002). Comparing VALERI sampling schemes to better represent high spatial resolution satellite pixel from ground measurements: How to characterize an ESU. Available for download at. http://w3.avignon.inra.fr/ valeri/methodology/samplingschemes.pdf (accessed 17/08/2011). 
Garrigues, S., Lacaze, R., Baret, F., Morisette, J. T., Weiss, M., Nickeson, J. E., Fernandes, R, Plummer, S., Shabanov, N. V., Myneni, R. B., Knyazikhin, Y., \& Yang, W. (2008). Validation and intercomparison of global Leaf Area Index products derived from remote sensing data. Journal of Geophysical Research, 113, doi:10.1029/2007JG000635.

Geiger, E. L., Gotsch, S. G., Damasco, G., Haridasan, M., Franco, A. C., \& Hoffmann, W. A (2011). Distinct roles of savanna and forest tree species in regeneration under fire suppression in a Brazilian savanna. Journal of Vegetation Science, 22, 312-321.

Gonsamo, A. (2009). Remote sensing of leaf area index: Enhanced retrieval from closerange and remotely sensed optical observations. Academic dissertation: Publicationes Instituti Geographici Universitatis Helsingiensis A147.

Gonsamo, A., \& Pellikka, P. (2008). Methodology comparison for slope correction in canopy leaf area index estimation using hemispherical photography. Forest Ecology and Management, 256, 749-759.

Gonsamo, A., \& Pellikka, P. (2009). The computation of foliage clumping index using hemispherical photography. Agricultural and Forest Meteorology, 149, 1781-1787.

Govender, N., Trollope, W. S. W., \& van Wilgen, B. W. (2006). The effect of fire season, fire frequency, rainfall and management on fire intensity in savanna vegetation in South Africa. Journal of Applied Ecology, 43, 748-758.

Haboudane, D., Miller, J. R., Pattey, E., Zarco-Tejada, P., \& Strachan, I. B. (2004). Hyperspectral vegetation indices and novel algorithms for predicting green LAI of crop canopies: Modeling and validation in the context of precision agriculture. Remote Sensing of Environment, 90, 337-352.

Hall, J., Burgess, N. D., Lovett, J., Mbilinyi, B., \& Gereau, R. E. (2009). Conservation implications of deforestation across an elevational gradient in the Eastern Arc Mountains, Tanzania. Biological Conservation, 142, 2510-2521.

Hely, C., Bremond, L., Allleaume, S., Smith, B., Sykes, M. T., \& Guiot, J. (2006). Sensitivity of African biomes to changes in the precipitation regime. Global Ecology and Biogeography, 15, 258-270.

Hijmans, R. J., Cameron, S. E., Parra, J. L., Jones, P. G., \& Jarvis, A. (2005). Very high resolution interpolated climate surfaces for global land areas. International Journal of Climatology, 25, 1965-1978.

Hill, M. J., Held, A. A., Leuning, R., Coops, N. C., Hughes, D., \& Cleugh, H. A. (2006). MODIS spectral signals at a flux tower site: Relationships with high-resolution data, and $\mathrm{CO}_{2}$ flux and light use efficiency measurements. Remote Sensing of Environment, $103,351-368$.

Holdo, R. M., Holt, R. D., \& Fryxell, J. M. (2009). Grazers, browsers and fire influence the extent and spatial pattern of tree cover in the Serengeti. Ecological Applications, 19, 95-109.

Hufkens, K., Bogaert, J., Dong, Q. H., Lu, L., Huang, C. L., Ma, M. G., et al. (2008). Impacts and uncertainties of upscaling remote-sensing data validation for a semi-arid woodland. Journal of Arid Environments, 72, 1490-1505.

Jacquemoud, S., \& Baret, F. (1990). Prospect - A model of leaf-optical properties spectra. Remote Sensing of Environment, 34, 75-91.

Jiang, Z., Huete, A. R., Didan, K., \& Miura, T. (2008). Development of a two-band enhanced vegetation index without a blue band. Remote Sensing of Environment, $112,3833-3845$

Jonckheere, I. G. C., Fleck, S., Nackaerts, K., Muys, B., Coppin, P., Weiss, M., \& Baret, F. (2004). Review of methods for in situ leaf area index determination - Part I. Theories, sensors and hemispherical photography. Agricultural and Forest Meteorology, $121,19-35$.

Jonckheere, B., Muys, B., \& Coppin, P. (2005). Allometry and optical in-situ LAI determination: A case-study in Belgium. Tree Physiology, 25, 723-732.

Jonckheere, I. G. C., Muys, B., \& Coppin, P. R. (2005). Derivative analysis for in situ high dynamic range hemispherical photography and its application in forest stands. IEEE Geoscience and Remote Sensing Letters, 2, 296-300.

Kalácska, M., Sanchez-Azofeita, G. A., Calvo-Alvarado, J. C., Journet, A. R. P., ArroyoMora, J. P., \& Ortiz-Ortiz, D. (2004). Leaf area index measurements in a tropical moist forest: A case study from Costa Rica. Remote Sensing of Environment, 91, 134-152.

Kalácska, M. E. R., Sanchez-Azofeita, G. A., Calvo-Alvarado, J. C., Rivard, B., \& Quesada, M. (2005). Effects of season and successional stage on leaf area index and spectral vegetation indices in three Mesoamerican tropical dry forests. Biotropica, 37. 486-496.

Kambatuku, J. R., Cramer, M. D., \& Ward, D. (2011). Savanna tree-grass competition is modified by substrate type and herbivory. Journal of Vegetation Science, 22, 225-237.

Kovacs, J. M., de Santiago, F. F., Bastien, J., \& Lafrance, P. (2010). An assessment of mangroves in Guinea, West Africa. Using a field and remote sensing based approach. Wetlands, 30, 773-782.

Kraus, T., Schmidt, M., Dech, S. W., \& Samimi, C. (2009). The potential of optical high resolution data for the assessment of leaf area index in East African rainforest ecosystems. International Journal of Remote Sensing, 30, 5039-5059.

Lang, A. R. G., \& Yueqin, X. (1986). Estimation of leaf area index from transmission of direct sunlight in discontinuous canopies. Agricultural and Forest Meteorology, 37, 229-243.

Launay, M., \& Guerif, M. (2005). Assimilating remote sensing data into a crop model to improve predictive performance for spatial applications. Agriculture, Ecosystems and Environment, 111, 321-339.

Lewis, P. E., \& Disney, M. I. (2007). Spectral invariants and scattering across multiple scales from within-leaf to canopy. Remote Sensing of Environment, 109, 196-206.

Lewis, S. L., Lopez-Gonzalez, G., Sonke, B., Affum-Baffoe, K., et al. (2009). Increasing carbon storage in intact African tropical forests. Nature, 457, 1003-1007.

Lindquist, J. L., Arkebauer, T. J., Walters, T. D., Cassman, K. G., \& Dobermann, A. (2005) Maize radiation use efficiency under optimal growth conditions. Agronomy Journal, 97, 72-78.

Lovett, J. C., Rudd, S., Taplin, J., \& Frimodt-Moller, C. (2000). Patterns of plant diversity in Africa south of the Sahara and their implications for conservation management. Biodiversity and Conservation, 9, 37-46.
Lovett, J. C., \& Wasser, S. K. (1993). Biogeography and ecology of the rainforests of eastern Africa. Cambridge: Cambridge University Press.

Malhado, A. C. M., Costa, M. H., de Lima, F. Z., Portilho, K. C., \& Figueiredo, D. N. (2009) Seasonal leaf dynamics in an Amazonian tropical forest. Forest Ecology and Management, 258, 1161-1165.

Marchant, R. (2010). Understanding complexity in savannas: Climate, biodiversity and people. Current Opinion in Environmental Sustainability, 2, 101-108.

Marchant, R., Mumbi, C., Behera, S., \& Yamagata, T. (2006). The Indian Ocean dipole The unsung driver of climatic variability in East Africa. African Journal of Ecology, 45 , 4-16.

Mittermeier, R. A., Gil, P. R., Hoffmann, M., Pilgrim, J., Brooks, T., Mittermeier, C. G., Lamoreux, J., \& da Fonseca, G. A. B. (2004). Hotspots revisited: Earth's biologically richest and most endangered ecoregions. Mexico City (Mexico): CEMEX.

Monteith, J. L., \& Unsworth, M. H. (1990). Principles of environmental physics. London: Edward Arnold.

Mougin, E., Hiernaux, P., Kergoat, L., Grippa, M., de Rosnay, P., et al. (2009). The AMMACATCH Gourma observatory site in Mali: Relating climatic variations to changes in vegetation, surface hydrology, fluxes and natural resources. Journal of Hydrology, $375,14-33$.

Myers, N., Mittermeier, R. A., Mittermeier, C. G., da Fonseca, G. A. B., \& Kent, J. (2000). Biodiversity hotspots for conservation priorities. Nature, 403, 853-858.

Myneni, R. B., Yang, W., Nemani, R. R., Huete, A. R., Dickinson, R. E., et al. (2007). Large seasonal swings in leaf area of Amazon rainforests. Proceedings of the National Academy of Sciences, 104, 4820-4823.

Nepstad, D. C., Stickler, C. M., Soares-Filho, B., \& Merry, F. (2008). Interactions among Amazon land use, forests and climate: Prospects for a near-term forest tipping point. Philosophical Transactions of the Royal Society of London. Series B, Biological Sciences, 363, 1737-1746.

Nicholson, S. E. (2000). The nature of rainfall variability over Africa on time scales of decades to millennia. Global and Planetary Change, 26, 137-158.

Nilson, T. (1971). A theoretical analysis of the frequency of gaps in plant stands. Agricultural Meteorology, 8, 25-38.

Oguntunde, P. G., \& van de Giesen, N. (2004). Crop growth and development effects on surface albedo for maize and cowpea fields in Ghana, West Africa. Internationa Journal of Biometeorology, 49, 106-112.

Palmer, D. J., Lowe, D. J., Payn, T. W., Höck, B. K., McLay, C. D. A., \& Kimberely, M. O. (2005). Soil and foliar phosphorus as indicators of sustainability for Pinus radiata plantation forestry in New Zealand. Forest Ecology and Management, 220, 140-154

Pellikka, P. K. E., Lötjönen, M., Siljander, M., \& Lens, L. (2009). Airborne remote sensing of spatiotemporal change (1955-2004) in indigenous and exotic forest cover in the Taita Hills, Kenya. International Journal of Applied Earth Observations and Geoinformation, 11, 221-232.

Pettorelli, N., Ryan, S., Mueller, T., Bunnefeld, N., Jedrzejewska, B., Lima, M., \& Kausrud, K. (2011). The Normalized Difference Vegetation Index (NDVI): Unforeseen successes in animal ecology. Climate Research, 46, 15-27.

Pfeifer, M., Disney, M., Quaife, T., \& Marchant, R., in press. Terrestrial ecosystems from space: A review of earth observation products for macroecology applications. Global Ecology and Biogeography. doi:10.1111/j.1466-8238.2011.00712.x. (Electronic publication ahead of print).

Pinto-Junior, O. B., Sanches, L., de Almeida Lobo, F., Brandão, A. A., \& de Souza Nogueira, J. (2011). Leaf area index of a tropical semi-deciduous forest of the southern Amazon Basin. International Journal of Biometeorology, 55, 109-118.

Platts, P., Lovett, J. C., Pellikka, P. K. E., Burgess, N., Swetnam, R., Marshall, A. R., et al (2011). Delimiting tropical mountain ecoregions for conservation. Environmental Conservation, 38, 312-324.

Privette, J. L., Myneni, R. B., Knyazikhin, Y., Mukelabai, M., Roberts, G., et al. (2002) Early spatial and temporal validation of MODIS LAI product in the Southern Africa Kalahari. Remote Sensing of Environment, 83, 232-243.

Qi, J., Chehbouni, A., Huete, A. R., Kerr, H. Y., \& Sorooshian, S. (1994). A modified soil adjusted vegetation index. Remote Sensing of Environment, 48, 119-126.

Raupach, M. R., Rayner, P. J., Barrett, D. J., DeFries, R. S., Heimann, M., Ojima, D. S., et al. (2005). Model-data synthesis in terrestrial carbon observation: Methods, data requirements, and data uncertainty specifications. Global Change Biology, 11, 378-397.

Ribeiro, N. S., Saatchi, S. S., Shugart, H. H. \& Washington-Allen, R. A. (2008). Aboveground biomass and leaf area index (LAI) mapping for Niassa Reserve, northern Mozambique. Journal of Geophysical Research, 113, doi:10.1029/2007JG000550.

Ribeiro, N. S., Shugart, H. H., \& Washington-Allen, R. (2008). The effects of fire and elephants on species composition and structure of the Niassa Reserve, northern Mozambique. Forest Ecology and Management, 255, 1626-1636.

Ridler, W., \& Calvard, S. (1978). Picture thresholding using an iterative selection method. IEEE Transactions on Systems, Man, and Cybernetics, 8, 260-263.

Rumpff, L., Duncan, D. H., Vesk, P. A., Keith, D. A., \& Wintle, B. A. (2011). State-and-transition modelling for adaptive management of native woodlands. Biological Conservation, 144, 1224-1236.

Running, S. W., Baldocchi, D. D., Turner, D. P., Gower, S. T., Bakwin, P. S., \& Hibbard, K. A (1999). A global terrestrial monitoring network integrating tower fluxes, flask sampling, ecosystem modelling and EOS satellite data. Remote Sensing of Environment, 70, 108-127.

Ryan, M. G., Hunt, E. R., Jr., McMurtrie, R. E., Agren, G. I., Aber, J. D., Friend, A. D., et al (1996). Comparing models of ecosystem function for temperate conifer forests. I. Model description and validation. In A. I. Breymeyer, D. O. Hall, J. M. Melillo, \& G.I. Agren (Eds.), Global change: Effects on coniferous forests and grasslands. London: John Wiley \& Sons.

Sabater, J. M., Ruediger, C., Calvet, J. -C., Fritz, N., Jarlan, L., \& Kerr, Y. (2008). Joint assimilation of surface soil moisture and LAI observations into a land surface model. $A g$ ricultural and Forest Meteorology, 148, 1362-1373. 
Sankaran, M., Hanan, N. P., Scholes, R. J., Ratnam, J., Augustine, D. J., Cade, B. S., et al. (2005). Determinants of woody cover in African savannas. Nature, 438, 846-849.

Schimel, D. S., Housel, J. I., Hibbard, K. A., Bousquet, P., Ciais, P., Peylin, P., Braswell, B. H., Apps, M. J., et al. (2001). Recent patterns and mechanisms of carbon exchange by terrestrial ecosystems. Nature, 414, 169-172.

Schleicher, J., Wiegand, K., \& Ward, D. (2011). Changes of woody plant interaction and spatial distribution between rocky and sandy soil areas in a semi-arid savannah, South Africa. Journal of Arid Environments, 75, 270-278.

Schreck, C. J., III, \& Semazzi, F. H. M. (2004). Variability of the recent climate of Eastern Africa. International Journal of Climatology, 24, 681-701.

Scurlock, J. M. O., Asner, G. P., \& Gower, S. T. (2001). Global Leaf Area Index data from field measurements, 1932-2000. Oak Ridge, Tennessee, U.S.A: Oak Ridge National Laboratory Distributed Active Archive Center http://www.daac.ornl.gov.

Sims, D. A., Rahman, A. F., Cordova, V. D., El-Masri, B. Z., Baldocchi, D. D., Flanagan, L. B., et al. (2006). On the use of MODIS EVI to assess gross primary productivity of North American ecosystems. Journal of Geophysical Research, 111, doi:10.1029/2006JG000162.

Sjöström, M., Ardö, J., Arneth, A., Boulain, N., et al. (2011). Exploring the potential of MODIS EVI for modeling gross primary production across African ecosystems. Remote Sensing of Environment, 115, 1081-1089.

Sone, C., Saito, K., \& Futakuchi, K. (2009). Comparison of three methods for estimating Leaf Area Index of upland rice cultivars. Crop Science, 49, 1438-1443.

Stoy, P. C., Williams, M., Spadavecchia, L., Cappelaere, B., Eklundh, L., de Grandcourt, A et al. (2009). Using information theory to determine optimal pixel size and shape for ecological studies: Aggregating land surface characteristics in Arctic ecosystems. Ecosystems, 12, 574-589.

Swetnam, R. D., Fisher, B., Mbilinyi, B. P., Munishi, P. K. T., Willcock, S., Ricketts, T., et al. (2011). Mapping socio-economic scenarios of land cover change: A GIS method to enable ecosystem service modelling. Journal of Environmental Management, 92, 563-574.

Taylor, J. A., \& Lloyd, J. (1992). Sources and sinks of atmospheric $\mathrm{CO}_{2}$. Australian Journa of Botany, 40, 407-418.
Wasseige, C., Bastin, D., \& Defourny, P. (2003). Seasonal variation of tropical forest LAI based on field measurements in Central African Republic. Agricultural and Forest Meteorology, 119, 181-194.

Webb, N., Nichol, C., Wood, J., \& Potter, E. (2008). User manual for the SunScan Canopy Analysis System, type SS1, Version: 2.0. Cambridge, U.K.: Delta-T Devices Ltd Download from. http://www.delta-t.co.uk/support-article.html?article=faq2008070800616 pp. 83.

Weiss, M., \& Baret, F., 2010. CAN-EYE V6.1 User Manual. EMMAH laboratory (Mediterranean environment and agro-hydro system modelisation). French National Institute of Agricultural Research (INRA).

Weiss, M., Baret, F., Myneni, R. B., Pragnère, A., \& Knyazikhin, Y. (2000). Investigation of a model inversion technique to estimate canopy biophysical variables from spectral and directional reflectance data. Agronomie, 20, 3-22.

Whitehead, D., \& Beadle, C. I. (2004). Physiological regulation of productivity and water use in Eucalyptus: A review. Forest Ecology and Management, 193, 113-140.

Wiegand, K. Saitz, D. \& Ward, D. (2006). A patch-dynamics approach to savannah dynamics and woody plant encroachment - Insights from an arid savannah. Perspectives in Plant Ecology, Evolution and Systematics, 7, 229-242.

Wilhelm, W., Ruwe, K., \& Schlemmer, M. R. (2000). Comparison of three Leaf Area Index meters in a corn canopy. Crop Science, 40, 1179-1183.

Williams, C. A., Hanan, N. P., Neff, J. C., Scholes, R. J., Berry, J. A., Denning, A. S., \& Baker, D. F. (2007). Africa and the global carbon cycle. Carbon Balance and Management, 2 , doi:10.1186/1750-0680-2-3.

Williams, M., Ryan, C. M., Rees, R. M., Sambane, E., Fernando, J., \& Grace, J. (2008). Carbon sequestration and biodiversity of re-growing Miombo woodlands in Mozambique. Forest Ecology and Management, 254, 145-155.

Zhang, Y., Chen, J. M., \& Miller, J. R. (2005). Determining digital hemispherical photograph exposure for leaf area index estimation. Agricultural and Forest Meteorology, 133, 166-181. 